\title{
Maternal effect of agronomic and morphological characters on cluster structure of F3 soybean lines
}

\author{
PANJI HANDOKO BADIARAJA ${ }^{1}$, SITI ZUBAIDAH ${ }^{1, \boldsymbol{v}}$, HERU KUSWANTORO ${ }^{2}$ \\ ${ }^{1}$ Department of Biology, Faculty of Mathematics and Natural Sciences, Universitas Negeri Malang. Jl. Semarang 5, Malang 65145, East Java, Indonesia \\ Tel.: +62-341-562180, "email: siti.zubaidah.fmipa@um.ac.id \\ ${ }^{2}$ Indonesian Legume and Tuber Crops Research Institute, Indonesian Agency for Agricultural Research and Development. Jl. Raya Kendalpayak Km. 8 , \\ Pakisaji, Malang 65101, East Java, Indonesia
}

Manuscript received: 30 December 2020. Revision accepted: 23 January 2021

\begin{abstract}
Badiaraja PH, Zubaidah S, Kuswantoro H. 2021. Maternal effect of agronomic and morphological characters on cluster structure of F3 soybean lines. Biodiversitas 22: 969-982. The study was to determine the maternal effect on the agronomic and morphological characters and their impact on F3 soybean lines cluster structure. The results showed the maternal effect was found in agronomic and morphological characters. In agronomic characters, the maternal effect was shown by plant height, number of productive nodes, number of filled pods, seed weight per plant, and 100-seed weight. In morphological characters, pod width, pod thickness, seed width, and seed thickness were shown by pod width. Based on cluster analysis results, at Grobogan/UM 3-2 cross, the best individuals for the number of branches, the number of productive nodes, the number of filled pods, the number of unfilled pods, the number of seeds per plant, and the seed yield per plant were obtained in Cluster 2. For the 100-seed weight, pod length, pod width, pod thickness, seed width, and seed thickness, the best individuals were in Cluster 1. Meanwhile, at UM 3-2/Grobogan cross, the best individuals for the plant height were in Cluster 2, while seed length was in Cluster 3. For the number of seeds per pod, the best individuals can be obtained from Cluster 6. The maternal-effect led to the cluster structure differed between cross and its reciprocal.
\end{abstract}

Keywords: Cluster analysis, maternal effect, soybean

\section{INTRODUCTION}

Soybean is one of the most important staple food in Indonesia (Julia et al. 2019). Also, soybeans are the primary source of protein and vegetable oil (Ge et al. 2016). The average national soybean consumption in 2018 was 2.3 million tons, while the national soybean production in 2018 was 983 thousand tons or around $43 \%$ of the need (Ministry of Agriculture, 2018). One of the effective ways to increase domestic soybean productivity is to develop high-yielding superior varieties. These superior varieties can be obtained through plant breeding programs.

Observation of agronomic character is crucial to support the success of plant breeding programs. It is because the agronomic character is a character that is directly related to soybean production, which is the goal of the plant breeding program (Ningsih et al. 2017). Besides, agronomic characters are the criteria used in the selection process to develop superior soybean varieties (Isnaini et al. 2020). One of the superior varieties of soybeans in Indonesia is the Grobogan variety. This variety can produce a seed yield of $3.40 \mathrm{t} / \mathrm{ha}$ with a 100 -seed weight of $18 \mathrm{~g} / 100$ seeds (Balitkabi 2016).

Apart from agronomic characters, it is also essential to observe morphological characters on pods and seeds. Information about morphological characters is useful for selecting high-yielding soybean lines (Ningsih et al. 2019). Observing the pods' morphological characters is vital because they are an assimilate storage organ in the form of seeds and protect the seeds from pests (Hidayatullah et al. 2017).

Agronomic and morphological characters are not regulated only by genes and the environment in which plants grow but also by the maternal effect (Gilsinger et al. 2010). Suppose a genotype carries characters affected by cytoplasm (maternal effect). In that case, the genes that regulate these characters will be expressed when the genotype in the female parent's position (Syukur et al. 2015). Therefore, offspring that have a character with a maternal effect also have similar characteristics to the female parent (Isnaini et al. 2020).

Several studies have reported a maternal effect on the agronomic and morphological characters of soybean plants. Isnaini et al. (2020) found a maternal effect on the plant height, the number of filled pods, seed yield per plant, and 100-seed weight. Ge et al. (2016) also reported a maternal effect on characters related to seed size. Knowledge of the maternal effect is advantageous so that plant breeding programs to form superior high-yielding soybean varieties can run more effectively. Genetic study of the maternal effect on F1 generation shows a maternal effect, while on F2 generation, it shows the number of controlling genes. In F3 generation, the maternal effect's presence and controlling genes lead to form the population structure of the lines. 


\section{MATERIALS AND METHODS}

\section{Study area}

The research was carried out in January-December 2019 at the Jambegede Research Station, Malang, East Java, Indonesia.

\section{Procedures}

Plant materials preparation

F3 soybean seeds were derived from a cross between the Grobogan variety with the UM 3-2 line, along with the UM 3-2/Grobogan reciprocal line. Grobogan variety is one of Indonesia's superior soybean varieties, producing a yield of $3.40 \mathrm{t} / \mathrm{ha}$ with a 100 -seed weight of $18 \mathrm{~g} / 100$ seeds. Simultaneously, UM 3-2 has high yield characteristics but has a small seed size $(<14 \mathrm{~g} / 100$ seeds).

\section{Planting soybean seeds}

This research was started by planting F3 soybean seeds in the Jambegede Research Station, Malang Regency, East Java. Soybean seeds were planted at a distance of $40 \times 15$ $\mathrm{cm}$ on land measuring $8 \times 1.5 \mathrm{~m}$. Each hole was filled with 3-4 seeds.

\section{Observation}

Agronomic character data were obtained by observing plant height, number of branches, number of productive nodes, number of filled pods, number of unfilled pods, number of seeds per plant, seed yield per plant, and 100seed weight. Morphological character data were obtained by observing pod length, pod width, pod thickness, number of seeds per pod, seed length, seed width, and seed thickness.

\section{Data analysis}

Agronomic and morphological data were analyzed for the unpaired t-test using the SPSS 24 program to determine a maternal effect. If there were a significant difference in a character between the Grobogan/UM 3-2 and the reciprocal, the character would indicate maternal effect. Cluster analysis was analyzed using Program R to cluster the Grobogan/UM 3-2 cross's performance and its reciprocal. The cluster method was applied by using the agronomic and morphological characters data.

\section{RESULTS AND DISCUSSION}

\section{Agronomic character description of $F 3$ soybean lines}

Based on the graph pattern of plant height in Figure 1, the Grobogan / UM 3-2 cross had one graphic peak in the middle with a value between $52-55 \mathrm{~cm}$. It indicates that most individual plants had a height close to the average. For the UM 3-2/Grobogan cross, the graph peaks were mostly on the right in the $53-57 \mathrm{~cm}$ range. It shows that most individual plants had a height above the average. The mean value of plant height for Grobogan/UM 3-2 cross was $53.55 \mathrm{~cm}$, while the reciprocal cross was $56.03 \mathrm{~cm}$. Based on the graph, individuals in the Grobogan/UM 3-2 had a height of about $80 \mathrm{~cm}$, while in the reciprocal cross, the maximum was about $70 \mathrm{~cm}$. The lowest plant height at the Grobogan/UM 3-2 cross was $33 \mathrm{~cm}$, while at the UM 32/Grobogan cross was $37 \mathrm{~cm}$.

For the number of branches character, the lowest value in the Grobogan/UM 3-2 cross was 1, while for the UM 32/Grobogan cross was 0. Based on Figure 2, the Grobogan/UM 3-2 cross and the reciprocal distribution pattern were average, with a peak in the middle, so that most individual plants at these two crosses had several branches close to the average value. The average value of the number of branches for the Grobogan/UM 3-2 cross was 3.854, while for the reciprocal, it was 3.719. Individuals achieved the highest number of branches at the UM 3-2/Grobogan crossing, namely nine branches.

Through Figure 3, the graph of the Grobogan/UM 3-2 cross had more than one peak (five peaks) in the 11-20 value range, whereas in the graph of the UM 3-2/Grobogan cross, it only had one peak in the 11-12 value range. It shows that the average number of productive nodes at the Grobogan/UM cross was 3-2 higher than the reciprocal. Besides, based on the Grobogan/UM 3-2 cross graph, some individuals had 41 productive nodes, while the recipient had at most 25 productive nodes. The average number of productive nodes at Grobogan/UM 3-2 cross is 17.59, while those at UM 3-2/Grobogan cross was 11.95.

The Grobogan/UM 3-2 cross has a graphic pattern with three peaks in the 25-35 value range, while the UM 32/Grobogan cross has a graphical pattern with distribution peaks in the 20-35 value range. The two crosses' distribution pattern shows a leftward inclination, which means that most individuals had lower filled pods than the average. The average value of the filled pods at Grobogan/UM 3-2 was 38.85, while the average value of the UM 3-2/Grobogan cross was 31.22. The number of filled pods in the Grobogan/UM 3-2 cross had at least 16 pods, and the highest was 105 pods, while the reciprocal had at least 13 pods and a maximum of 72 pods (Figure 4).

In Figure 5, the distribution pattern of individuals at the Grobogan/UM 3-2 cross showed a left-leaning (positive skewness) pattern, with the distribution peak on the left of the graph in the value range 1-2. The UM 3-2/Grobogan cross's distribution pattern also showed a left-leaning pattern with the distribution peak at value 1 . The graph pattern skewed to the left shows that the two crosses individuals mostly have unfilled pods below the mean average. The Grobogan/UM 3-2 cross had an average value of 1.7 for the number of unfilled pods, while the UM 3$2 /$ Grobogan cross was 1.63. The range of values for the number of unfilled pods at the Grobogan/UM 3-2 cross was $0-6$, while the UM 3-2/Grobogan cross was 0-4. The UM 3$2 /$ Grobogan cross had a smaller number of pods than the Grobogan/UM 3-2 cross.

The maximum number of seeds per plant at the Grobogan/UM 3-2 cross reached 235 seeds, which was more than the maximum number of seeds per plant at the UM 3-2/Grobogan cross, which only reached 179 seeds. The average number of seeds per plant in the Grobogan/UM 3-2 cross was 78.8, while the UM 32/Grobogan cross was 76.26. At the graphic pattern, most of the individual plants at the Grobogan/UM 3-2 cross and 
their reciprocal had fewer seeds than the average value. The peak distribution at the Grobogan/UM 3-2 cross was in the range of 50-66 seeds, while at the UM 3-2/Grobogan cross was in the range of 70-76 seeds (Figure 6).

The highest mean value was owned by the Grobogan/UM 3-2 cross on the seed yield per plant, which was $11.33 \mathrm{~g}$, while the average seed yield per plant at the UM 3-2/Grobogan cross was $9.9 \mathrm{~g}$ (Table 1). The range of seed yield values per plant at the Grobogan/UM 3-2 cross was 3.48-36.64 g, while at the UM 3-2/Grobogan cross was 3.4-24.41 g. The distribution pattern of individuals on the seeds' weight per plant for the two crosses is presented in Figure 7. For the Grobogan/UM 3-2 cross, the distribution pattern was skewed to the left so that the majority of individuals had below-average seed yield per plant. The same distribution pattern was also shown by the UM 32/Grobogan cross leaning to the left. Therefore, the seed yield value per plant of most individuals at this cross was below the average value. The Grobogan/UM 3-2 cross's peak distribution was in the range of 4-6 g, while the UM 3-2/Grobogan was in the range of 9-10 $\mathrm{g}$ (Figure 7).

Based on the 100-seed weight chart pattern for the Grobogan/UM 3-2 cross, the distribution peak was at the value of $14 \mathrm{~g}$, while at the UM 3-2/Grobogan cross was in the range of 12-13 g. The overall value range for the $100-$ seed weight character for the Grobogan/UM 3-2 cross was 7.6-19.76 g, while the 100-seed weight for the UM 32/Grobogan cross was $8.72-17.24 \mathrm{~g}$. The 100 -seed weight graph for the two crosses is shown in Figure 8. Based on this figure, both crosses' graph pattern was typical, so most individuals had a 100-seed weight close to the average value. The Grobogan/UM 3-2 cross's average value was $14.33 \mathrm{~g}$, while the average value for the 100 -seed weight at the UM 3-2/Grobogan cross was $12.93 \mathrm{~g}$ (Figure 8).

Table 1. Maternal effect on agronomic and morphological characters F3 soybean lines of Grobogan/UM 3-2 cross, and it's reciprocal

\begin{tabular}{lccc}
\hline Characters & Grobogan/UM 3-2 & UM 3-2/Grobogan & Significance (2-tailed) \\
\hline Plant height (cm) & $53.55 \pm 8.81$ & $56.03 \pm 5.6$ & $0.000^{* *}$ \\
Number of branches & $3.85 \pm 1.27$ & $3.72 \pm 1.25$ & 0.283 \\
Number of productive nodes & $17.59 \pm 5.62$ & $11.95 \pm 3.54$ & $0.000^{* *}$ \\
Number of filled pods & $38.85 \pm 14.91$ & $31.22 \pm 11.3$ & $0.000^{* *}$ \\
Number of unfilled pods & $1.7 \pm 1.21$ & $1.63 \pm 0.84$ & 0.481 \\
Number of seed per plant & $78.8 \pm 32.56$ & $76.26 \pm 28.92$ & 0.403 \\
Seed yield per plant (g) & $11.33 \pm 4.88$ & $9.9 \pm 3.82$ & $0.000^{* *}$ \\
100-seed weight (g) & $14.33 \pm 1.81$ & $12.93 \pm 1.1$ & $0.000^{* *}$ \\
Pod length (mm) & $43.51 \pm 5.27$ & $42.65 \pm 4.15$ & 0.061 \\
Pod width (mm) & $9.14 \pm 0.63$ & $8.09 \pm 0.96$ & $0.000^{* *}$ \\
Pod thickness (mm) & $5.75 \pm 0.54$ & $5.46 \pm 0.32$ & $0.000^{* *}$ \\
Number of seed per pod & $2.71 \pm 0.47$ & $2.74 \pm 0.46$ & 0.464 \\
Seed length (mm) & $7.38 \pm 0.47$ & $7.44 \pm 0.44$ & 0.210 \\
Seed width (mm) & $6.41 \pm 0.29$ & $6.25 \pm 0.29$ & $0.000^{* *}$ \\
Seed thickness (mm) & $5.01 \pm 0.3$ & $4.86 \pm 0.24$ & $0.000^{* *}$ \\
\hline Note: Signifin
\end{tabular}

Note: *: Significant at $0.05, * *$ : Significant at 0.01 .
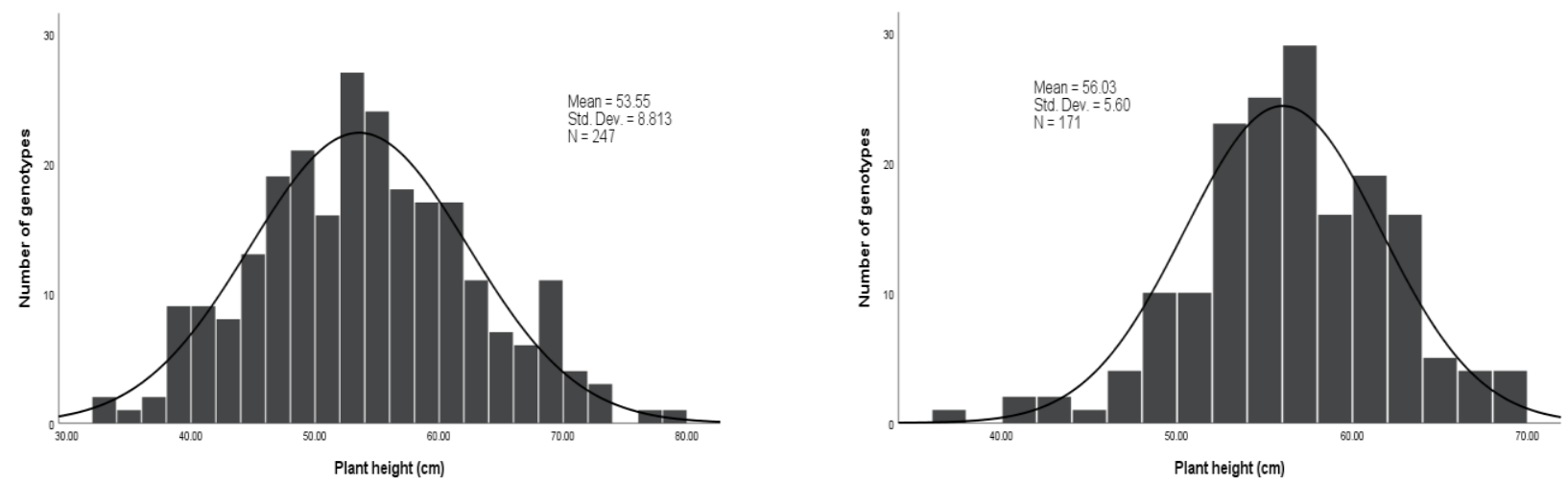

Figure 1. Plant height of Grobogan/UM 3-2 (left) and UM 3-2/Grobogan (right) 

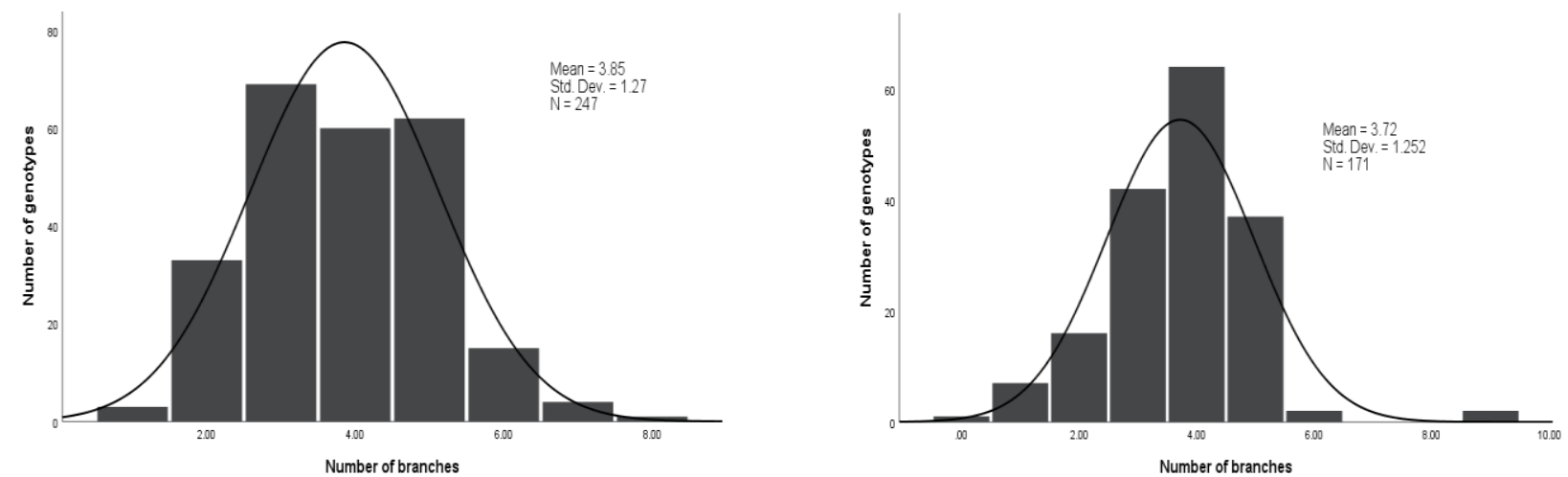

Figure 2. Number of branches of Grobogan/UM 3-2 (left) and UM 3-2/Grobogan (right)
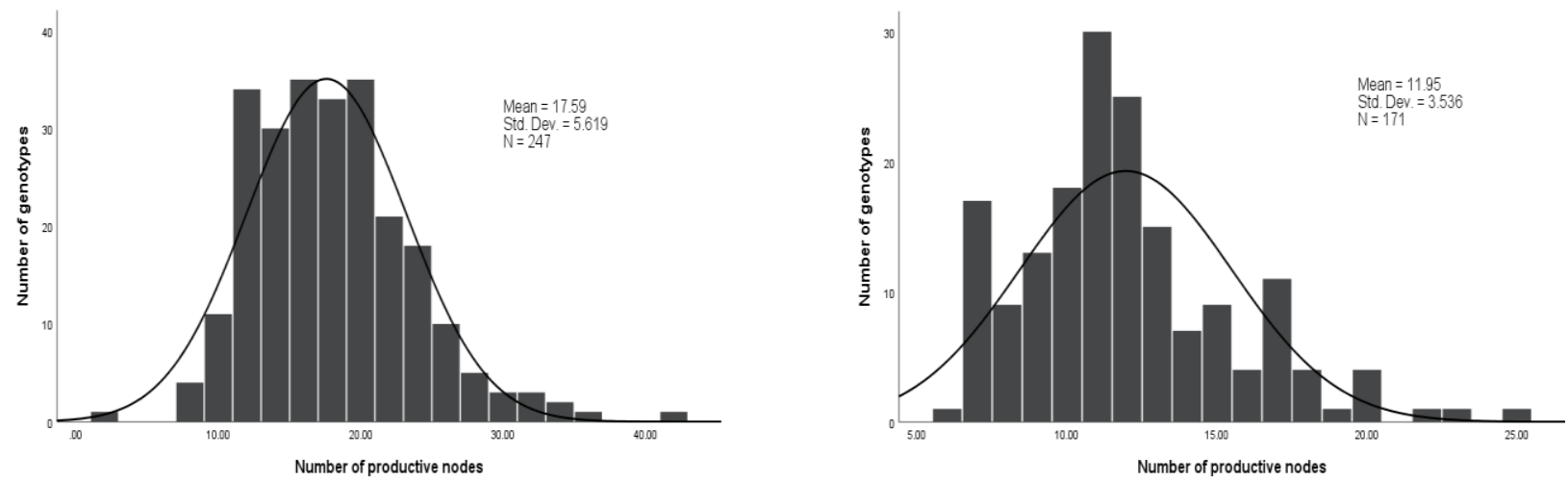

Figure 3. Number of productive nodes of Grobogan/UM 3-2 (left) and UM 3-2/Grobogan (right)
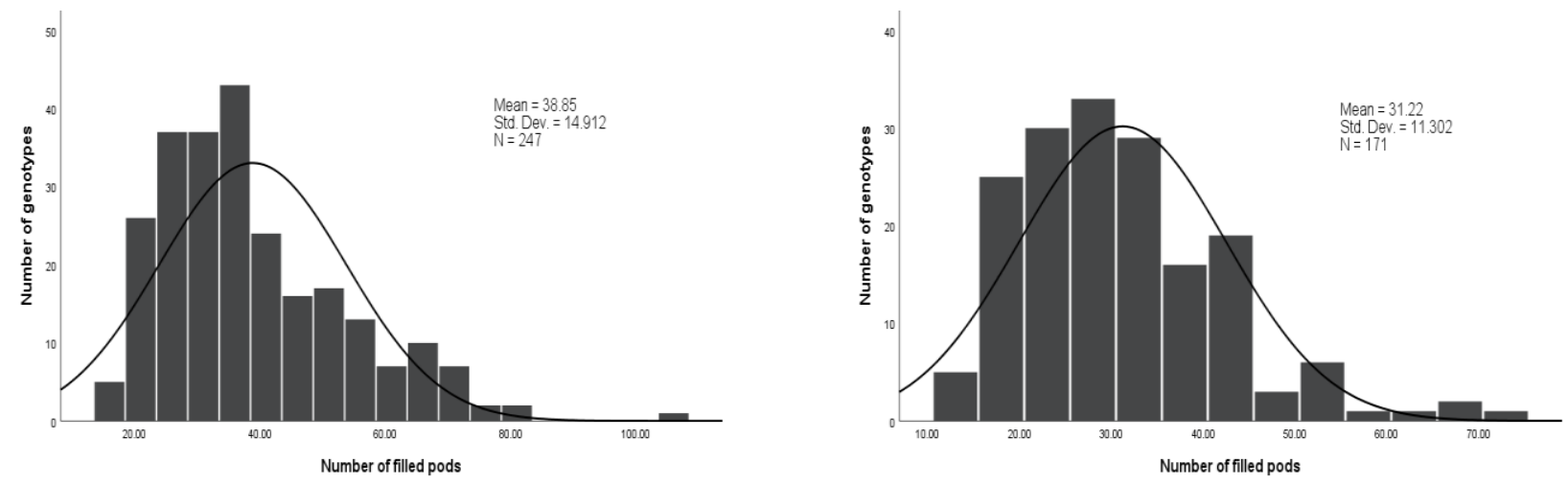

Figure 4. Number of filled pods of Grobogan/UM 3-2 (left) and UM 3-2/Grobogan (right)
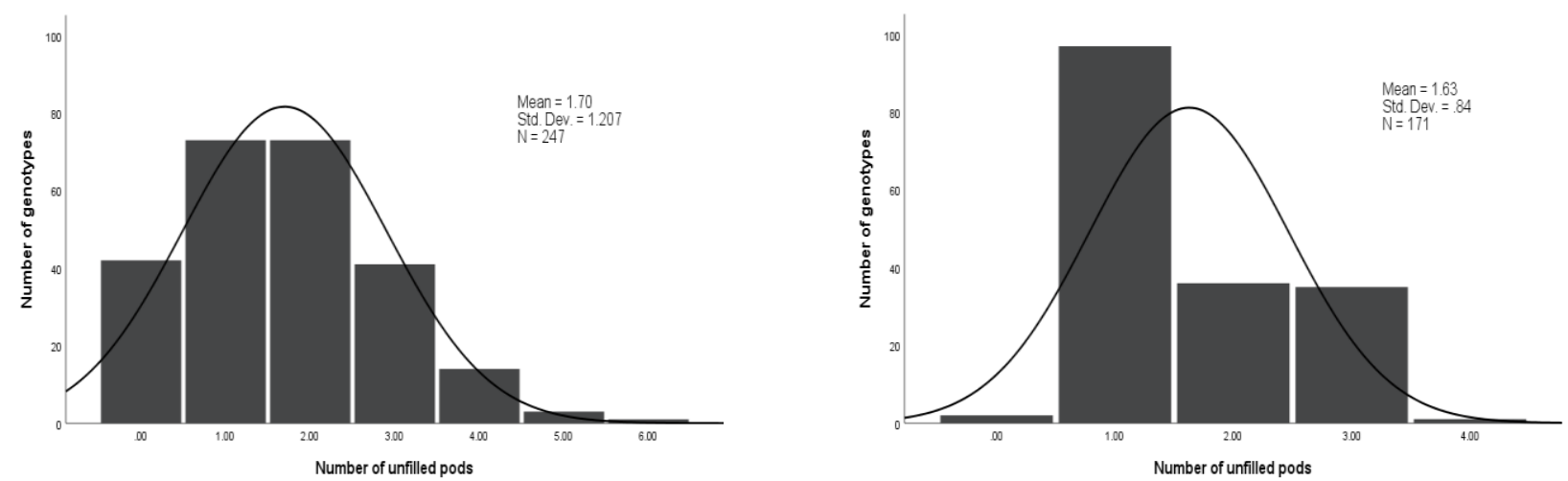

Figure 5. Number of unfilled pods of Grobogan/UM 3-2 (left) and UM 3-2/Grobogan (right) 

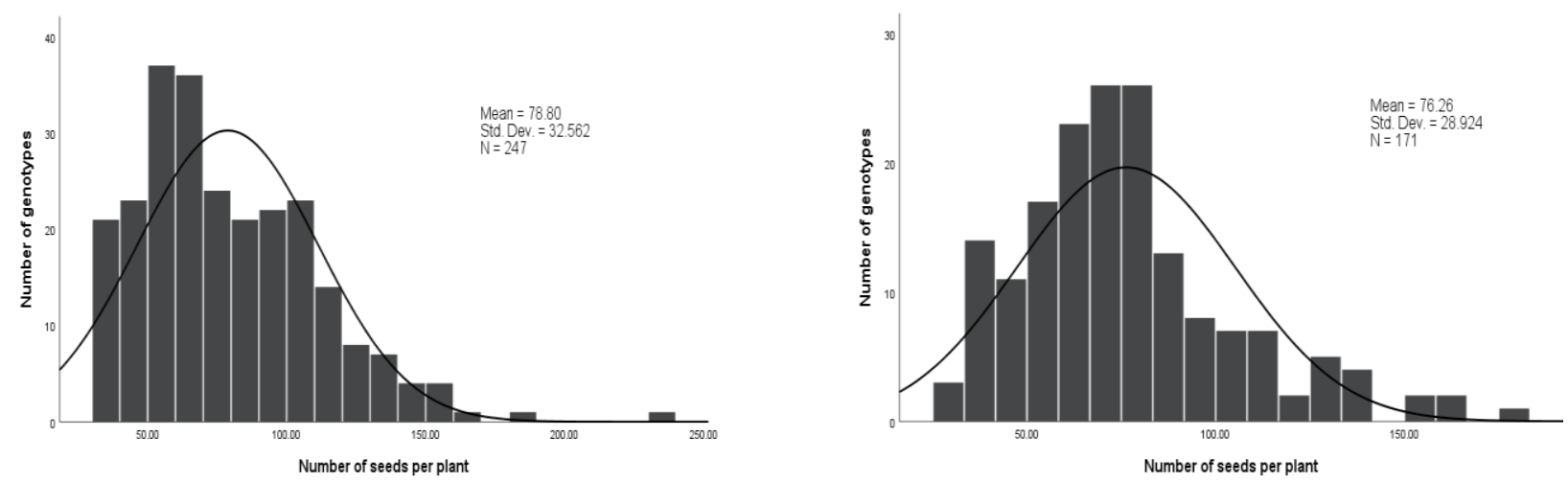

Figure 6. Number of seeds per plant of Grobogan/UM 3-2 (left) and UM 3-2/Grobogan (right)
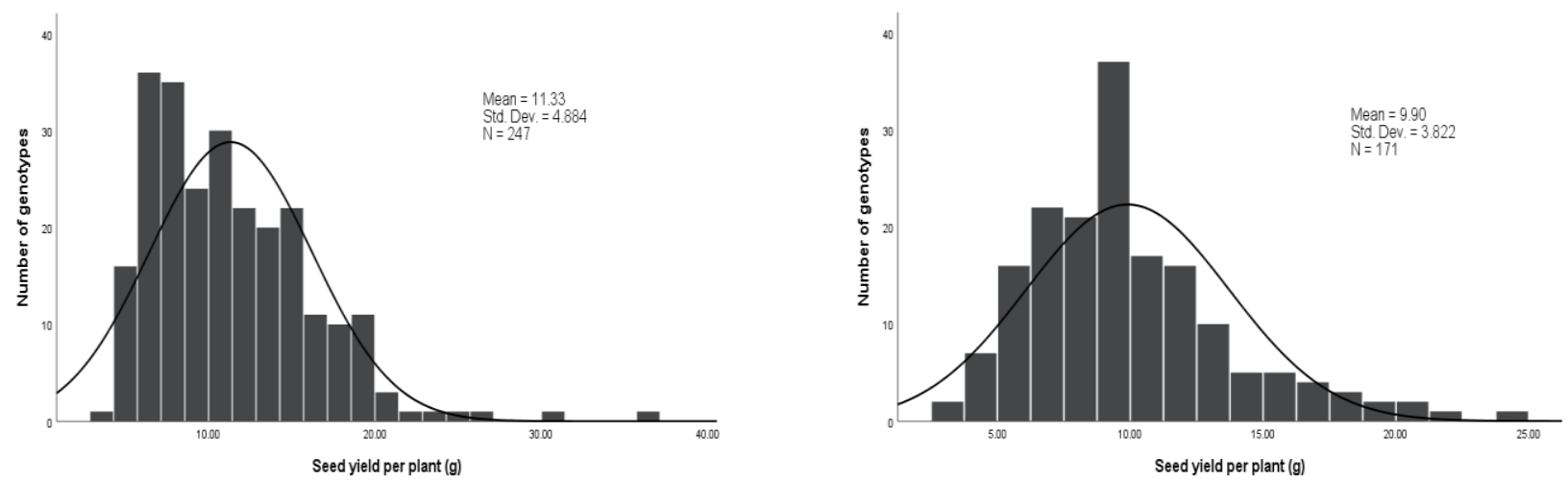

Figure 7. Seed yield per plant of Grobogan/UM 3-2 (left) and UM 3-2/Grobogan (right)
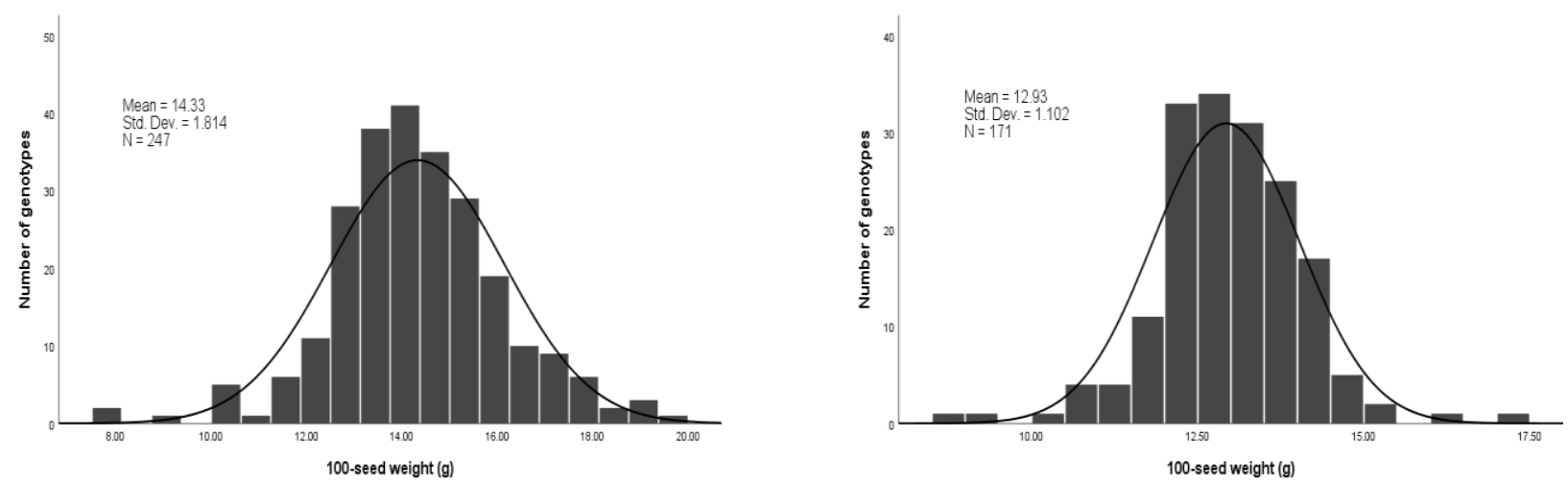

Figure 8. 100-seed weight of Grobogan/UM 3-2 (left) and UM 3-2/Grobogan (right)

\section{Morphological character description of F3 soybean lines}

Based on Figure 9, the range of values for pod length characters at the Grobogan/UM 3-2 cross was 30-57 mm. Most genotypes at Grobogan/UM 3-2 cross had pod length values of 42-46 mm. UM 3-2/Grobogan cross also had a similar range of values for $31-58 \mathrm{~mm}$ pod length characters. The highest number of genotypes in the UM 3 2/Grobogan cross had a pod length value of $45 \mathrm{~mm}$. The Grobogan/UM 3-2 cross had the highest average value for the pod length character, $43.51 \mathrm{~mm}$. Meanwhile, the UM 32/Grobogan cross had an average pod length value of 42.65 mm (Table 1).
The Grobogan/UM 3-2 cross had pod width 6.24-11.04 $\mathrm{mm}$ with the largest pod width of $8.5 \mathrm{~mm}$. The UM 32/Grobogan cross had lower pod width, where the range was 4.93-9.79 mm, with the highest pod width of $8.5 \mathrm{~mm}$ (Figure 10). The Grobogan/UM 3-2 cross had the highest average value for the pod width character, $9.14 \mathrm{~mm}$, while the UM 3-2/Grobogan cross had an average pod width value of $8.09 \mathrm{~mm}$ (Table 1 ).

Figure 11 shows that the value ranges for pod thickness characters at the Grobogan/UM 3-2 cross were 4.36-9.46 $\mathrm{mm}$. It can also be seen that the individuals at this cross mostly had a pod thickness of mm. At the Grobogan/UM 3- 
2 cross, the range of values for pod thickness was 4.62-6.42 $\mathrm{mm}$. The highest individual number of genotypes at UM 3 2/Grobogan cross had pod thickness as much as $5.50 \mathrm{~mm}$. The Grobogan/UM 3-2 cross had the highest average value for the pod thickness character, which was $5.75 \mathrm{~mm}$, while the UM 3-2/Grobogan cross had an average value for the pod thickness character of $5.46 \mathrm{~mm}$ (Table 1).

The UM 3-2/Grobogan cross obtained the highest average value for the number of seeds per pod, which was 2.74. Meanwhile, at the Grobogan/UM 3-2 cross, the average value for the number of seeds per pod was 2.71 (Table 1). The number of seeds per pod in the Grobogan/UM 3-2 cross ranged from 2-4. The highest number of genotypes in the Grobogan/UM 3-2 cross had three seeds per pod. The number of seeds per pod at the UM 3-2/Grobogan cross had a range of values of 2-4. The highest individual number of genotypes at the UM 32/Grobogan cross also had an amount of 3 seeds per pod (Figure 12).

The highest average value was obtained by the UM 32/Grobogan cross, which was 2.74. Meanwhile, the average seed length value at the Grobogan/UM 3-2 cross was 7.38 $\mathrm{mm}$ (Table 1). The range of seed length values at the Grobogan/UM 3-2 cross was 6.1-8.95 mm. It is similar to the range values at the UM 3-2/Grobogan cross, namely 6.06-8.49. The genotypes in the Grobogan/UM 3-2 cross mostly had a seed length of $7.25 \mathrm{~mm}$, but the highest number of genotypes at the UM 3-2/Grobogan cross for seed length was $7.4 \mathrm{~mm}$ (Figure 13).

The Grobogan/UM 3-2 cross had a higher average value for the seed width than the UM 3-2/Grobogan cross, with an average of 6.41 and 6.25, respectively (Table 1). The range of seed width values at the Grobogan/UM 3-2 cross was 5.33-7.2 mm. The highest number of genotypes of individuals at the Grobogan/UM 3-2 cross had a seed width value of $\mathrm{mm}$. The range of seed width values at the UM 3-2/Grobogan cross was 5.04-6.97 mm. The UM 32/Grobogan cross mostly had seed width values of 6.1-6.5 $\mathrm{mm}$ (Figure 14).

The Grobogan/UM 3-2 cross had the highest average value for the grain thickness character of $5.01 \mathrm{~mm}$, while the UM 3-2/Grobogan cross had an average seed thickness value of $4.86 \mathrm{~mm}$ (Table 1). Figure 15 shows the range of grain thickness values at the Grobogan/UM3.2 cross was 3.97-5.86 mm. The Grobogan/UM 3-2 cross mostly had seed thickness of $4.75-5.25 \mathrm{~mm}$. The range of seed thickness values at the UM 3-2/Grobogan cross was 4-5.47 $\mathrm{mm}$, with the most genotypes in $5-5.10 \mathrm{~mm}$.
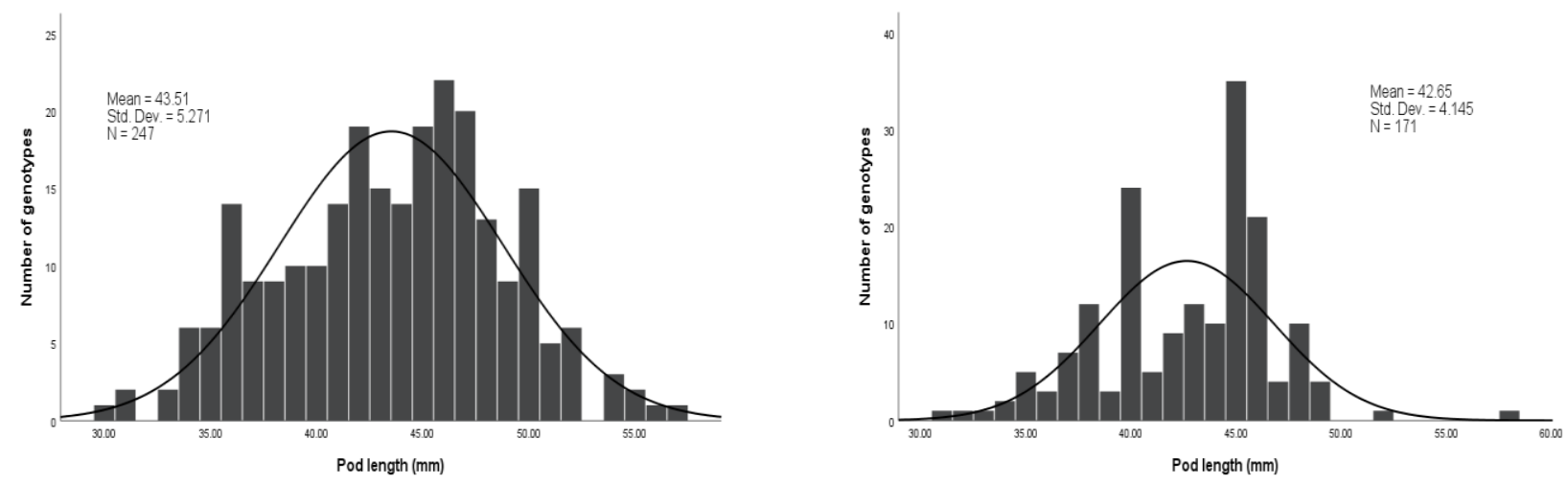

Figure 9. Pod length of Grobogan/UM 3-2 (left) and UM 3-2/Grobogan (right)
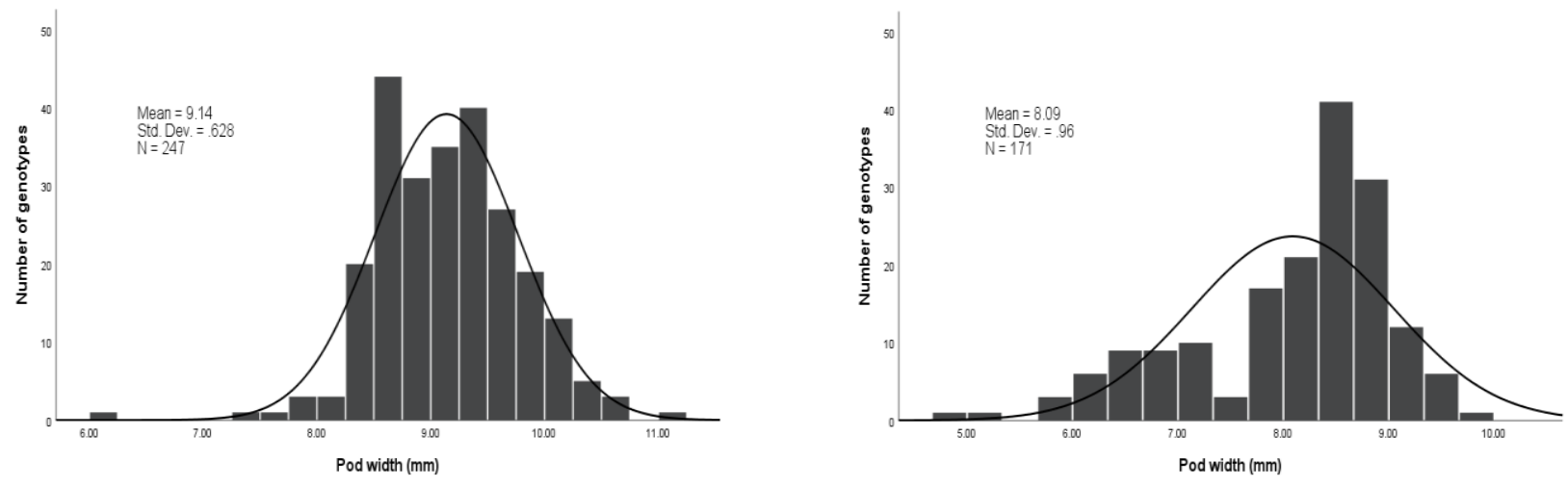

Figure 10. Pod width of Grobogan/UM 3-2 (left) and UM 3-2/Grobogan (right) 

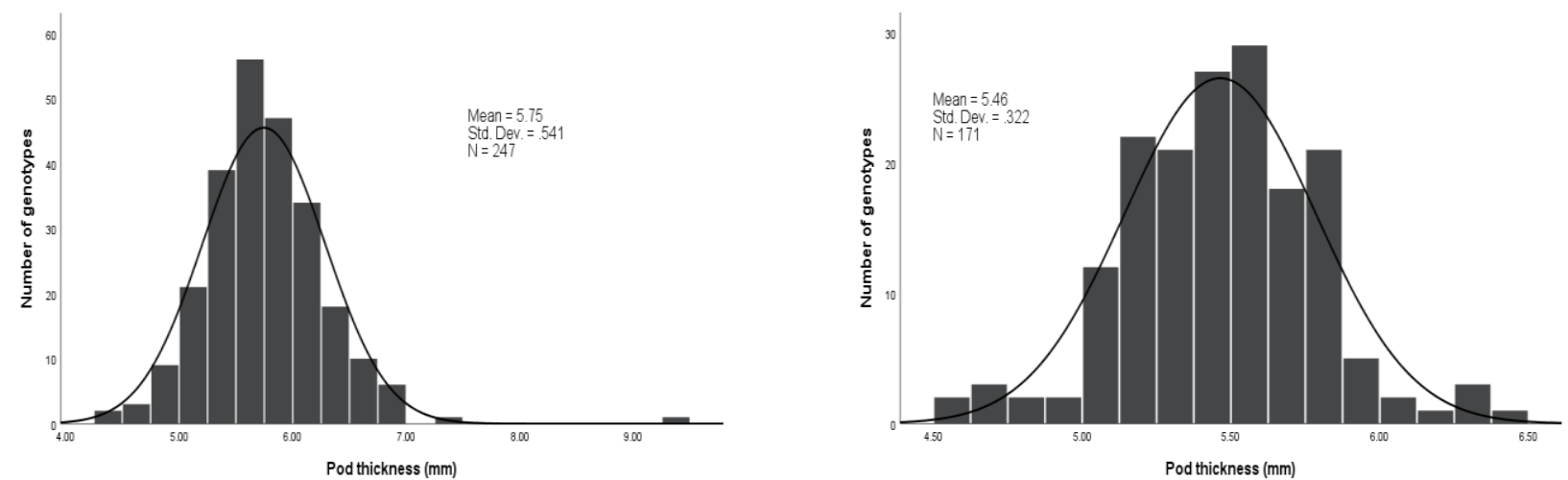

Figure 11. Pod thickness of Grobogan/UM 3-2 (left) and UM 3-2/Grobogan (right)
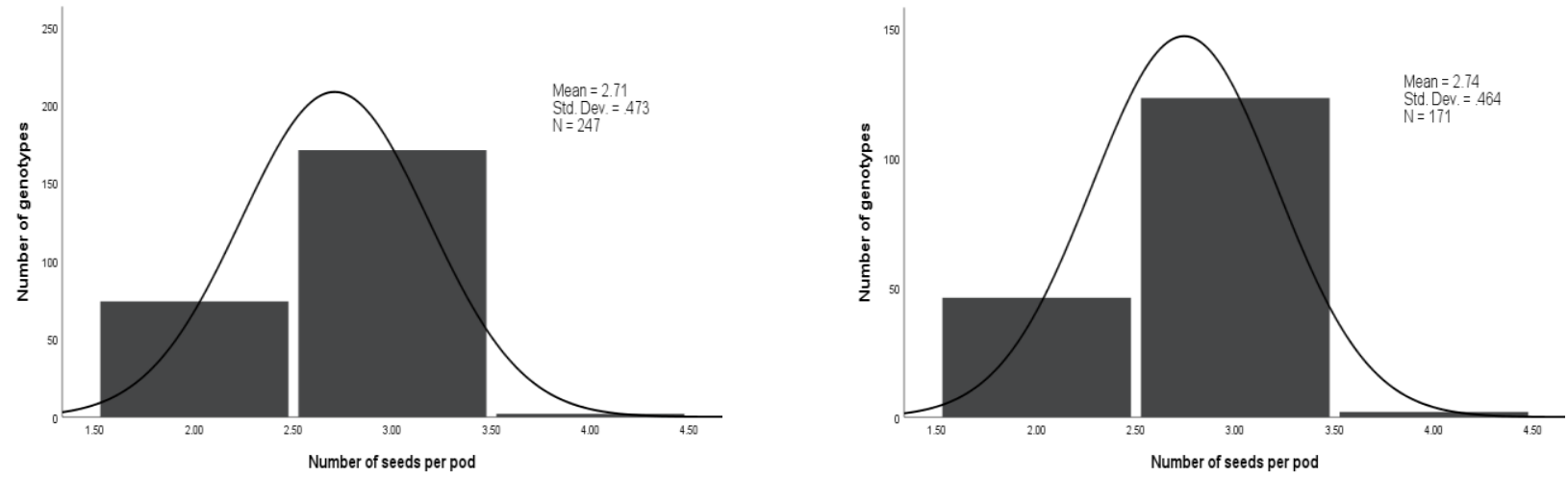

Figure 12. Number of seeds per pod of Grobogan/UM 3-2 (left) dan UM 3-2/Grobogan (right)
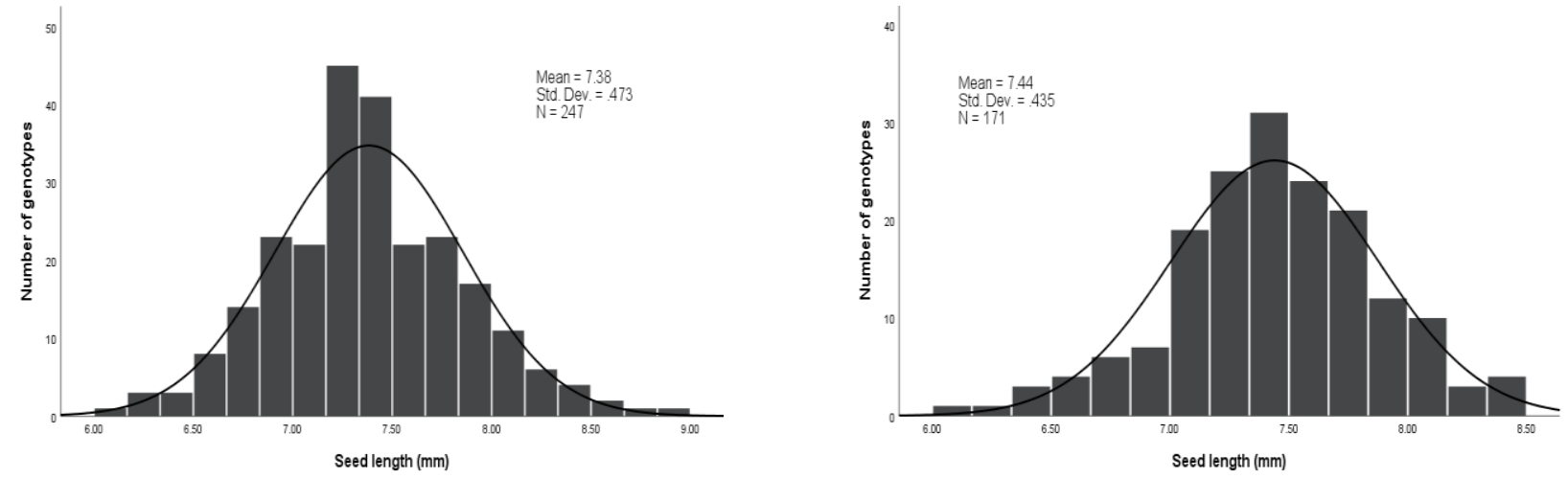

Figure 13. Seed length of Grobogan/UM 3-2 (left) and UM 3-2/Grobogan (right)
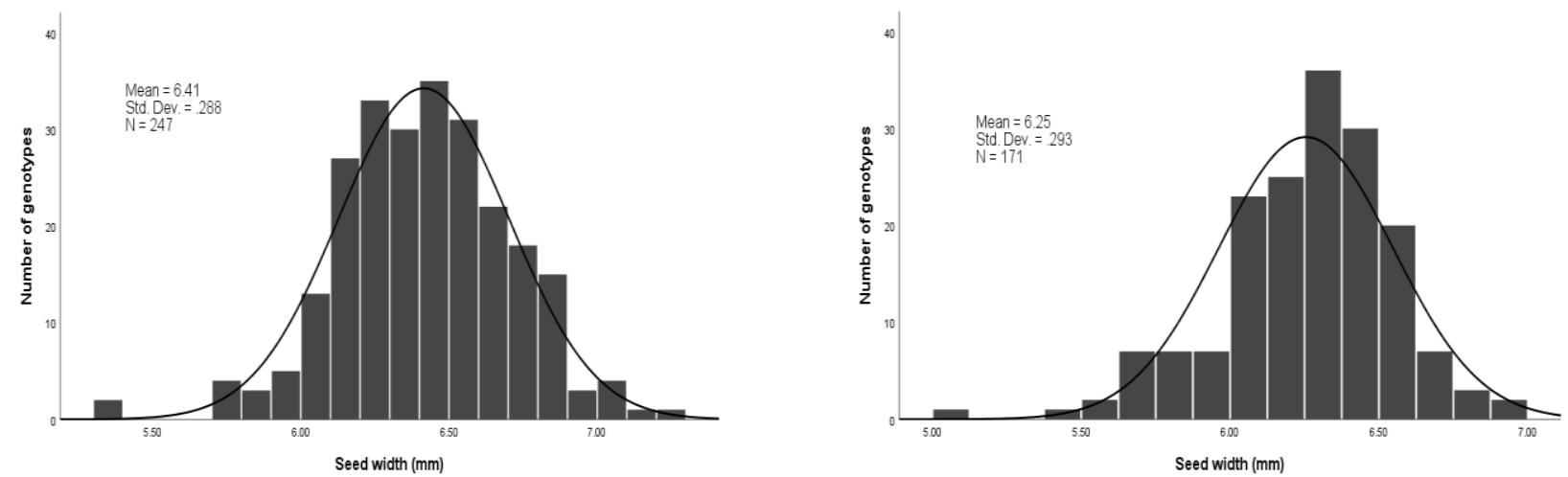

Figure 14. Seed width of Grobogan/UM 3-2 (left) and UM 3-2/Grobogan (right) 

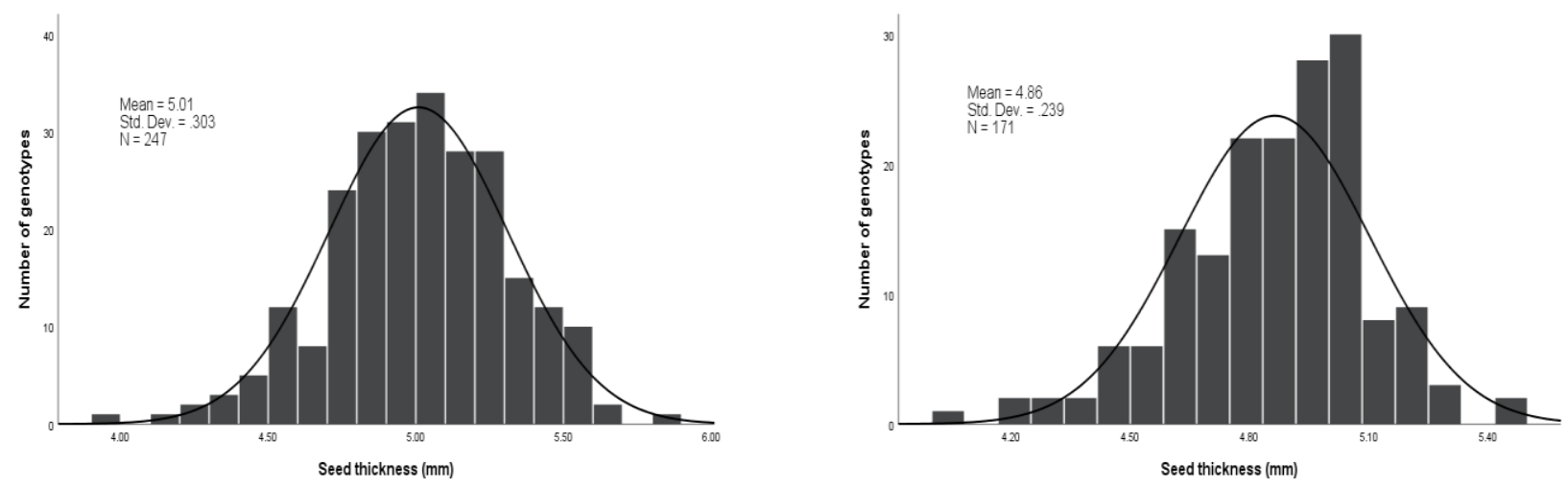

Figure 15. Seed thickness of Grobogan/UM 3-2 (left) and UM 3-2/Grobogan (right)

\section{Maternal effect on agronomical and morphological characters}

From the t-test, it was found that there were very significant differences in the characters of plant height, number of productive nodes, number of filled pods, seed yield per plant, 100-seed weight, pod width, pod thickness, seed width, and seed thickness. Conversely, the insignificant differences were shown by the number of branches, number of unfilled pods, number of seeds per plant, length of pods, number of seeds per pod, and seed length (Table 1).

\section{The cluster structure of F3 soybean lines}

Cluster analysis was conducted to classify the F3 soybean cross genotypes between Grobogan/UM 3-2 and UM 3-2/Grobogan. The visualization of the cluster analysis results of the lines is presented as a dendrogram in Figure 16. The Grobogan/UM 3-2 cross is divided into 6 clusters, which are shown with different color displays. Each cluster has a different number of genotypes and clusters. Details of cluster genotypes can be seen in Table 2, while cluster characteristics can be seen from the highest and lowest average values in Table 3 .

Based on Table 2, Cluster 3 was the cluster with the most members, namely 66 genotypes, while Cluster 1 was the smallest with 14 genotypes. Cluster 2 consisted of 29 individuals, while Cluster 4 consisted of 48 individuals. Cluster 5 had 53 genotypes, while Cluster 6 had 37 members. The branching on the dendrogram (Figure 16) indicated the closeness between clusters, where Cluster 1 had a closeness to Cluster 2, while Cluster 3 had a closeness to Cluster 6.

Based on Table 3, Cluster 1 had the highest value for the characters of plant height $(61.21 \mathrm{~cm}), 100$-seed weight $(15.97 \mathrm{~g})$, pod thickness $(6.39 \mathrm{~mm})$, seed length $(8.10)$, seed width $(6.81 \mathrm{~mm})$, and seed thickness $(5.43 \mathrm{~mm})$. Cluster 2 had the highest value for the characters number of branches (5.45), number of productive nodes (26.86), number of filled pods (63.59), number of unfilled pods (2.83), number of seeds per plant $(130,90)$, and the seed yield per plant (18.68 g). Clusters 3 and 4 did not have the highest score for any of the characters. Cluster 5 had the highest value for the number of seeds per pod (3.02).
Cluster 6 had the highest value for the pod width $(9.75$ $\mathrm{mm})$.

The cluster analysis results for the UM 3-2/Grobogan cross are presented in the form of a dendrogram in Figure 17. The details of which individuals from the UM 32/Grobogan cross were collected in the cluster (Table 4). The characteristics of each cluster can be seen in Table 5. Dendrogram for the UM 3-2/Grobogan line (Figure 17) showed the closeness between clusters. Cluster 1 was close to Cluster 6, compared to other clusters. Cluster 3 had the most members, namely 44 genotypes, while Cluster 4 had 43 members (Table 4). Cluster 6 had 36 members, while Cluster 2 had 20 individuals belonging to it. Clusters 1 and 2 had fewer members than the other clusters, namely 15 and 13 individuals, respectively (Table 4).

Based on Table 5, clusters 1, 4, and 5 did not show the highest value for any character. Cluster 2 showed the highest values for plant height $(60.25 \mathrm{~cm})$, number of productive nodes (17.30), number of filled pods (49.60), number of seeds per plant (128.65), pod length $(45,35$ $\mathrm{mm})$, pod thickness $(5.73 \mathrm{~mm})$, and seed thickness (5.01 $\mathrm{mm})$. Cluster 3 showed the highest values for the 100 -seed weight $(13.62 \mathrm{~g})$, pod width $(8.75 \mathrm{~mm})$, seed length $(7.66$ $\mathrm{mm})$, and seed width $(6.39 \mathrm{~mm})$. Cluster 6 had the highest values for the number of branches (4.39), the number of unfilled pods (2.06), and the number of seeds per pod (3.00).

Based on Tables 2 and 4, Cluster 3 of the two crosses had the most members. Likewise, for Cluster 1 of the two crosses, both had the least members. Based on Tables 3 and 5, Cluster 1 in the Grobogan/UM 3-2 cross had the highest value for six characters, while the UM 3-2/Grobogan cross did not show the highest value for any character. Cluster 2 in both crosses showed dominance in many characters. Cluster 3 in the Grobogan/UM 3-2 cross was not dominant in any of the characters, while in the reciprocal cross, Cluster 3 was dominant in four characters. Cluster 4 in both crosses did not have a high value for any of the characters. Cluster 5 and 6 in the Grobogan/UM 3-2 cross were dominant in one character, while Cluster 5 in the UM 3$2 /$ Grobogan cross was not represented by any characters. Cluster 6 at the UM 3-2/Grobogan cross was represented by three characters. 


\section{Discussion}

Information about the maternal effect is crucial in the plant breeding process. Information about the maternal effect is useful to determine the female parent's role in the inheritance pattern of agronomic and morphological characters, especially characters related to soybean yield productivity. Information about the maternal effect can then be used to choose the right parent combination to increase the chances of obtaining high yielding soybean in the next generation. The existence of a maternal effect on offspring can be identified by performing reciprocal crosses, where reciprocal cross pairs will have a gene contribution from the same cell nucleus. Therefore, if there are differences in the offspring's characters' appearance, these differences can be caused by the maternal effect (Roach \& Wulff 1987).

Table 1 provides maternal effect information on the agronomic characters of the F3 generation of the Grobogan/UM 3-2 crossbreed soybean and its reciprocal UM 3-2/Grobogan. Based on this table, the maternal effect was not found on the number of branches, number of unfilled pods, and number of seeds per plant (Table 1). These three characteristics are probably regulated by a combination of genes from the male and female parent (Gilsinger et al. 2010). This result is supported by Isnaini et al. (2020), who reported no maternal effect on the number of branches.

The maternal-effect was found in plant height, number of productive nodes, number of filled pods, seed yield per plant, and 100-seed weight. Isnaini et al. (2020) also reported a maternal effect on plant height, number of filled pods, seed yield per plant, and 100-seed weight, but not on the number of productive nodes. The difference in results on the number of productive nodes is probably due to differences in the parent's varieties. The variety used in the study of Isnaini et al. (2020) is the Panderman variety, while this study uses the Grobogan variety. Apart from genetic diversity, the number of productive nodes is also influenced by the number of branches. An increase will follow an increase in the number of branches in the number of productive nodes (Kuswantoro 2017).

Table 2. Lines in a cluster of Grobogan/UM 3-2 cross

\begin{tabular}{|c|c|c|c|c|c|c|c|c|}
\hline Cluster & & & & & & & & \\
\hline 1 & G/3.2-1 & G/3.2-7 & $\mathrm{G} / 3.2-72$ & G/3.2-101 & G/3.2-157 & $\mathrm{G} / 3.2-170$ & G/3.2-182 & $\mathrm{G} / 3.2-189$ \\
\hline & G/3.2-199 & G/3.2-203 & G/3.2-219 & $\mathrm{G} / 3.2-227$ & $\mathrm{G} / 3.2-230$ & G/3.2-235 & & \\
\hline 2 & G/3.2-2 & $\mathrm{G} / 3.2-10$ & G/3.2-11 & G/3.2-18 & $\mathrm{G} / 3.2-32$ & G/3.2-37 & $\mathrm{G} / 3.2-56$ & $\mathrm{G} / 3.2-58$ \\
\hline & G/3.2-61 & $\mathrm{G} / 3.2-62$ & $\mathrm{G} / 3.2-66$ & $\mathrm{G} / 3.2-84$ & G/3.2-91 & $\mathrm{G} / 3.2-94$ & G/3.2-96 & G/3.2-98 \\
\hline & $\mathrm{G} / 3.2-110$ & $\mathrm{G} / 3.2-112$ & G/3.2-115 & $\mathrm{G} / 3.2-120$ & G/3.2-124 & $\mathrm{G} / 3.2-160$ & G/3.2-178 & G/3.2-179 \\
\hline & G/3.2-196 & $\mathrm{G} / 3.2-200$ & $\mathrm{G} / 3.2-201$ & $\mathrm{G} / 3.2-236$ & $\mathrm{G} / 3.2-243$ & & & \\
\hline 3 & G/3.2-3 & G/3.2-4 & $\mathrm{G} / 3.2-5$ & G/3.2-13 & $\mathrm{G} / 3.2-19$ & $\mathrm{G} / 3.2-22$ & $\mathrm{G} / 3.2-24$ & $\mathrm{G} / 3.2-30$ \\
\hline & G/3.2-41 & $\mathrm{G} / 3.2-45$ & G/3.2-46 & G/3.2-47 & G/3.2-48 & $\mathrm{G} / 3.2-50$ & G/3.2-53 & G/3.2-54 \\
\hline & $\mathrm{G} / 3.2-57$ & $\mathrm{G} / 3.2-59$ & G/3.2-60 & G/3.2-68 & $\mathrm{G} / 3.2-73$ & G/3.2-81 & $\mathrm{G} / 3.2-82$ & $\mathrm{G} / 3.2-83$ \\
\hline & $\mathrm{G} / 3.2-85$ & G/3.2-97 & $\mathrm{G} / 3.2-100$ & $\mathrm{G} / 3.2-106$ & G/3.2-108 & $\mathrm{G} / 3.2-114$ & G/3.2-116 & $\mathrm{G} / 3.2-118$ \\
\hline & G/3.2-119 & G/3.2-125 & G/3.2-134 & $\mathrm{G} / 3.2-141$ & G/3.2-142 & $\mathrm{G} / 3.2-150$ & G/3.2-151 & G/3.2-153 \\
\hline & G/3.2-156 & G/3.2-158 & $\mathrm{G} / 3.2-169$ & $\mathrm{G} / 3.2-174$ & G/3.2-175 & G/3.2-176 & G/3.2-181 & G/3.2-184 \\
\hline & G/3.2-194 & G/3.2-206 & G/3.2-207 & $\mathrm{G} / 3.2-210$ & $\mathrm{G} / 3.2-213$ & G/3.2-214 & G/3.2-218 & G/3.2-223 \\
\hline & $\mathrm{G} / 3.2-224$ & G/3.2-225 & $\mathrm{G} / 3.2-229$ & $\mathrm{G} / 3.2-232$ & G/3.2-237 & $\mathrm{G} / 3.2-238$ & G/3.2-239 & G/3.2-241 \\
\hline & G/3.2-244 & G/3.2-245 & & & & & & \\
\hline 4 & G/3.2-6 & G/3.2-8 & $\mathrm{G} / 3.2-14$ & $\mathrm{G} / 3.2-16$ & G/3.2-17 & $\mathrm{G} / 3.2-31$ & $\mathrm{G} / 3.2-38$ & G/3.2-49 \\
\hline & $\mathrm{G} / 3.2-51$ & $\mathrm{G} / 3.2-52$ & G/3.2-63 & G/3.2-67 & G/3.2-74 & $\mathrm{G} / 3.2-75$ & $\mathrm{G} / 3.2-76$ & G/3.2-77 \\
\hline & G/3.2-78 & G/3.2-80 & G/3.2-89 & G/3.2-93 & G/3.2-104 & G/3.2-121 & $\mathrm{G} / 3.2-122$ & G/3.2-126 \\
\hline & $\mathrm{G} / 3.2-127$ & $\mathrm{G} / 3.2-128$ & $\mathrm{G} / 3.2-130$ & $\mathrm{G} / 3.2-132$ & G/3.2-135 & G/3.2-139 & G/3.2-145 & $\mathrm{G} / 3.2-146$ \\
\hline & G/3.2-148 & G/3.2-152 & G/3.2-159 & $\mathrm{G} / 3.2-162$ & G/3.2-163 & G/3.2-164 & $\mathrm{G} / 3.2-180$ & G/3.2-185 \\
\hline & G/3.2-188 & G/3.2-191 & G/3.2-192 & $\mathrm{G} / 3.2-212$ & $\mathrm{G} / 3.2-216$ & G/3.2-217 & $\mathrm{G} / 3.2-228$ & G/3.2-231 \\
\hline 5 & G/3.2-9 & $\mathrm{G} / 3.2-12$ & G/3.2-15 & $\mathrm{G} / 3.2-20$ & $\mathrm{G} / 3.2-23$ & G/3.2-25 & $\mathrm{G} / 3.2-26$ & G/3.2-27 \\
\hline & G/3.2-29 & G/3.2-33 & G/3.2-35 & G/3.2-39 & G/3.2-42 & G/3.2-43 & G/3.2-44 & G/3.2-65 \\
\hline & G/3.2-71 & G/3.2-79 & G/3.2-86 & G/3.2-90 & G/3.2-92 & G/3.2-105 & G/3.2-107 & $\mathrm{G} / 3.2-111$ \\
\hline & $\mathrm{G} / 3.2-113$ & G/3.2-131 & G/3.2-136 & G/3.2-137 & G/3.2-138 & G/3.2-143 & G/3.2-144 & G/3.2-147 \\
\hline & G/3.2-149 & G/3.2-155 & G/3.2-165 & G/3.2-166 & G/3.2-167 & G/3.2-168 & G/3.2-171 & G/3.2-173 \\
\hline & G/3.2-177 & G/3.2-190 & G/3.2-193 & G/3.2-197 & G/3.2-202 & G/3.2-204 & G/3.2-209 & $\mathrm{G} / 3.2-211$ \\
\hline & $\mathrm{G} / 3.2-220$ & G/3.2-221 & $\mathrm{G} / 3.2-234$ & $\mathrm{G} / 3.2-240$ & G/3.2-246 & & & \\
\hline 6 & G/3.2-21 & G/3.2-28 & G/3.2-34 & $\mathrm{G} / 3.2-36$ & $\mathrm{G} / 3.2-40$ & G/3.2-55 & G/3.2-64 & G/3.2-69 \\
\hline & $\mathrm{G} / 3.2-70$ & $\mathrm{G} / 3.2-87$ & $\mathrm{G} / 3.2-88$ & G/3.2-95 & G/3.2-99 & $\mathrm{G} / 3.2-102$ & G/3.2-103 & G/3.2-109 \\
\hline & $\mathrm{G} / 3.2-117$ & $\mathrm{G} / 3.2-123$ & $\mathrm{G} / 3.2-129$ & $\mathrm{G} / 3.2-133$ & $\mathrm{G} / 3.2-140$ & G/3.2-154 & G/3.2-161 & $\mathrm{G} / 3.2-172$ \\
\hline & G/3.2-183 & G/3.2-186 & $\mathrm{G} / 3.2-187$ & G/3.2-195 & G/3.2-198 & G/3.2-205 & G/3.2-208 & G/3.2-215 \\
\hline & G/3.2-222 & G/3.2-226 & G/3.2-233 & G/3.2-242 & G/3.2-247 & & & \\
\hline
\end{tabular}


Table 3. Mean values of agronomy and morphological characters in the cluster of Grobogan/UM 3-2 cross.

\begin{tabular}{|c|c|c|c|c|c|c|c|c|c|c|c|c|c|c|c|}
\hline Cluster & $\mathbf{X 1}$ & $\mathbf{X} 2$ & $\mathbf{X 3}$ & X4 & X5 & X6 & $\mathbf{X} 7$ & X8 & X9 & X10 & X11 & X12 & X13 & X14 & X15 \\
\hline 1 & 61.21 & 4.29 & 20.71 & 49.64 & 1.93 & 96.00 & 15.40 & 15.97 & 50.36 & 9.47 & 6.39 & 3.00 & 8.10 & 6.81 & 5.43 \\
\hline 2 & 56.14 & 5.45 & 26.86 & 63.59 & 2.83 & 130.90 & 18.68 & 14.18 & 41.93 & 9.08 & 5.74 & 2.62 & 7.30 & 6.43 & 5.08 \\
\hline 3 & 48.71 & 3.05 & 13.67 & 29.39 & 1.56 & 56.36 & 8.06 & 14.35 & 46.79 & 9.18 & 6.10 & 3.00 & 7.55 & 6.54 & 5.17 \\
\hline 4 & 50.92 & 3.35 & 14.63 & 30.92 & 1.33 & 64.81 & 8.61 & 13.27 & 39.50 & 8.67 & 5.30 & 2.48 & 6.92 & 6.10 & 4.74 \\
\hline 5 & 58.92 & 4.57 & 20.13 & 43.77 & 1.47 & 92.13 & 13.37 & 14.46 & 45.13 & 9.03 & 5.63 & 3.02 & 7.22 & 6.31 & 4.85 \\
\hline 6 & 52.97 & 3.51 & 16.32 & 35.51 & 1.76 & 70.51 & 10.47 & 14.94 & 39.22 & 9.75 & 5.61 & 2.00 & 7.71 & 6.59 & 5.09 \\
\hline
\end{tabular}

Note: X1: plant height $(\mathrm{cm}) ; \mathrm{X} 2$ : number of branches; X3: number of reproductive nodes; X4: number of filled pods; X5: number of unfilled pods; X6: number of seeds per plant; X7: seed yield per plant (g); X8: 100-seed weight (g); X9: pod length (mm); X10: pod width (mm); X11: pod thickness; X12: number of seeds per pod; X13: seed length (mm); X14: seed width (mm); X15: seed thickness $(\mathrm{mm})$.

Table 4. Lines in the cluster of UM 3-2/Grobogan cross

\begin{tabular}{|c|c|c|c|c|c|c|c|c|}
\hline \multirow{3}{*}{$\begin{array}{c}\text { Cluster } \\
1\end{array}$} & \multicolumn{8}{|c|}{ Lines } \\
\hline & $3.2 / \mathrm{G}-1$ & $3.2 / \mathrm{G}-15$ & $3.2 / \mathrm{G}-17$ & $3.2 / \mathrm{G}-24$ & $3.2 / \mathrm{G}-49$ & $3.2 / \mathrm{G}-55$ & 3.2/G-61 & $3.2 / \mathrm{G}-76$ \\
\hline & $3.2 / \mathrm{G}-78$ & $3.2 / \mathrm{G}-83$ & $3.2 / \mathrm{G}-107$ & $3.2 / \mathrm{G}-118$ & $3.2 / \mathrm{G}-123$ & $3.2 / \mathrm{G}-132$ & $3.2 / \mathrm{G}-170$ & \\
\hline \multirow[t]{3}{*}{2} & $3.2 / \mathrm{G}-2$ & $3.2 / \mathrm{G}-3$ & $3.2 / \mathrm{G}-13$ & $3.2 / \mathrm{G}-14$ & 3.2/G-19 & $3.2 / \mathrm{G}-21$ & $3.2 / \mathrm{G}-23$ & $3.2 / \mathrm{G}-38$ \\
\hline & $3.2 / \mathrm{G}-40$ & $3.2 / \mathrm{G}-57$ & $3.2 / \mathrm{G}-60$ & $3.2 / \mathrm{G}-63$ & 3.2/G-99 & $3.2 / \mathrm{G}-110$ & $3.2 / \mathrm{G}-150$ & 3.2/G-151 \\
\hline & $3.2 / \mathrm{G}-152$ & $3.2 / \mathrm{G}-162$ & $3.2 / \mathrm{G}-166$ & $3.2 / \mathrm{G}-169$ & & & & \\
\hline \multirow[t]{6}{*}{3} & $3.2 / \mathrm{G}-4$ & $3.2 / \mathrm{G}-5$ & $3.2 / \mathrm{G}-6$ & $3.2 / \mathrm{G}-10$ & $3.2 / \mathrm{G}-11$ & 3.2/G-12 & $3.2 / \mathrm{G}-29$ & $3.2 / \mathrm{G}-30$ \\
\hline & $3.2 / \mathrm{G}-31$ & $3.2 / \mathrm{G}-34$ & $3.2 / \mathrm{G}-42$ & $3.2 / \mathrm{G}-45$ & $3.2 / \mathrm{G}-51$ & $3.2 / \mathrm{G}-53$ & 3.2/G-66 & 3.2/G-67 \\
\hline & 3.2/G-71 & $3.2 / \mathrm{G}-72$ & $3.2 / \mathrm{G}-73$ & $3.2 / \mathrm{G}-82$ & $3.2 / \mathrm{G}-85$ & $3.2 / \mathrm{G}-86$ & 3.2/G-90 & 3.2/G-91 \\
\hline & 3.2/G-92 & 3.2/G-95 & $3.2 / \mathrm{G}-100$ & 3.2/G-101 & 3.2/G-108 & 3.2/G-109 & $3.2 / \mathrm{G}-111$ & $3.2 / \mathrm{G}-113$ \\
\hline & $3.2 / \mathrm{G}-115$ & $3.2 / \mathrm{G}-116$ & $3.2 / \mathrm{G}-121$ & $3.2 / \mathrm{G}-139$ & $3.2 / \mathrm{G}-140$ & $3.2 / \mathrm{G}-145$ & $3.2 / \mathrm{G}-158$ & $3.2 / \mathrm{G}-161$ \\
\hline & $3.2 / \mathrm{G}-164$ & $3.2 / \mathrm{G}-167$ & $3.2 / \mathrm{G}-168$ & $3.2 / \mathrm{G}-171$ & & & & \\
\hline \multirow[t]{6}{*}{4} & $3.2 / \mathrm{G}-7$ & $3.2 / \mathrm{G}-18$ & $3.2 / \mathrm{G}-25$ & $3.2 / \mathrm{G}-26$ & $3.2 / \mathrm{G}-27$ & $3.2 / \mathrm{G}-28$ & $3.2 / \mathrm{G}-32$ & $3.2 / \mathrm{G}-35$ \\
\hline & $3.2 / \mathrm{G}-37$ & $3.2 / \mathrm{G}-39$ & $3.2 / \mathrm{G}-43$ & $3.2 / \mathrm{G}-47$ & $3.2 / \mathrm{G}-50$ & $3.2 / \mathrm{G}-52$ & $3.2 / \mathrm{G}-56$ & $3.2 / \mathrm{G}-65$ \\
\hline & $3.2 / \mathrm{G}-68$ & $3.2 / \mathrm{G}-69$ & $3.2 / \mathrm{G}-75$ & $3.2 / \mathrm{G}-77$ & $3.2 / \mathrm{G}-87$ & $3.2 / \mathrm{G}-88$ & $3.2 / \mathrm{G}-89$ & 3.2/G-94 \\
\hline & $3.2 / \mathrm{G}-96$ & $3.2 / \mathrm{G}-98$ & $3.2 / \mathrm{G}-102$ & $3.2 / \mathrm{G}-103$ & $3.2 / \mathrm{G}-106$ & $3.2 / \mathrm{G}-114$ & $3.2 / \mathrm{G}-117$ & $3.2 / \mathrm{G}-122$ \\
\hline & $3.2 / \mathrm{G}-128$ & $3.2 / \mathrm{G}-130$ & $3.2 / \mathrm{G}-131$ & $3.2 / \mathrm{G}-133$ & $3.2 / \mathrm{G}-137$ & $3.2 / \mathrm{G}-143$ & $3.2 / \mathrm{G}-147$ & $3.2 / \mathrm{G}-148$ \\
\hline & $3.2 / \mathrm{G}-149$ & $3.2 / \mathrm{G}-155$ & $3.2 / \mathrm{G}-157$ & & & & & \\
\hline \multirow[t]{2}{*}{5} & $3.2 / \mathrm{G}-8$ & $3.2 / \mathrm{G}-16$ & $3.2 / \mathrm{G}-20$ & $3.2 / \mathrm{G}-46$ & $3.2 / \mathrm{G}-64$ & $3.2 / \mathrm{G}-74$ & 3.2/G-97 & 3.2/G-112 \\
\hline & $3.2 / \mathrm{G}-125$ & $3.2 / \mathrm{G}-126$ & $3.2 / \mathrm{G}-127$ & 3.2/G-134 & $3.2 / \mathrm{G}-141$ & & & \\
\hline \multirow[t]{5}{*}{6} & $3.2 / \mathrm{G}-9$ & $3.2 / \mathrm{G}-22$ & $3.2 / \mathrm{G}-33$ & $3.2 / \mathrm{G}-36$ & $3.2 / \mathrm{G}-41$ & $3.2 / \mathrm{G}-44$ & $3.2 / \mathrm{G}-48$ & $3.2 / \mathrm{G}-54$ \\
\hline & $3.2 / \mathrm{G}-58$ & $3.2 / \mathrm{G}-59$ & $3.2 / \mathrm{G}-62$ & $3.2 / \mathrm{G}-70$ & $3.2 / \mathrm{G}-79$ & $3.2 / \mathrm{G}-80$ & $3.2 / \mathrm{G}-81$ & $3.2 / \mathrm{G}-84$ \\
\hline & 3.2/G-93 & $3.2 / \mathrm{G}-104$ & $3.2 / \mathrm{G}-105$ & $3.2 / \mathrm{G}-119$ & $3.2 / \mathrm{G}-120$ & $3.2 / \mathrm{G}-124$ & 3.2/G-129 & 3.2/G-135 \\
\hline & $3.2 / \mathrm{G}-136$ & $3.2 / \mathrm{G}-138$ & $3.2 / \mathrm{G}-142$ & $3.2 / \mathrm{G}-144$ & $3.2 / \mathrm{G}-146$ & $3.2 / \mathrm{G}-153$ & $3.2 / \mathrm{G}-154$ & $3.2 / \mathrm{G}-156$ \\
\hline & $3.2 / \mathrm{G}-159$ & $3.2 / \mathrm{G}-160$ & $3.2 / \mathrm{G}-163$ & 3.2/G-165 & & & & \\
\hline
\end{tabular}

Table 5. Mean values of agronomy and morphological characters in the cluster of UM 3-2/Grobogan cross

\begin{tabular}{|c|c|c|c|c|c|c|c|c|c|c|c|c|c|c|c|}
\hline Cluster & X1 & $\mathrm{X} 2$ & $\mathbf{X 3}$ & X4 & X5 & X6 & $\mathbf{X} 7$ & X8 & X9 & X10 & X11 & X12 & X13 & X14 & X15 \\
\hline 1 & 56.40 & 4.07 & 14.33 & 39.93 & 1.93 & 98.67 & 12.86 & 12.97 & 42.00 & 8.06 & 5.18 & 2.93 & 7.08 & 5.93 & 4.62 \\
\hline 2 & 60.25 & 4.10 & 17.30 & 49.60 & 1.90 & 128.65 & 16.80 & 13.00 & 45.35 & 8.42 & 5.73 & 2.90 & 7.47 & 6.21 & 5.01 \\
\hline 3 & 56.05 & 3.34 & 10.89 & 29.00 & 1.27 & 68.91 & 9.33 & 13.62 & 44.86 & 8.75 & 5.67 & 2.98 & 7.66 & 6.39 & 5.00 \\
\hline 4 & 54.51 & 3.65 & 11.12 & 28.58 & 1.44 & 68.12 & 8.82 & 12.89 & 38.35 & 7.01 & 5.36 & 2.21 & 7.61 & 6.34 & 4.86 \\
\hline 5 & 54.92 & 2.38 & 8.46 & 19.31 & 1.46 & 46.23 & 5.82 & 12.47 & 41.00 & 7.86 & 5.13 & 2.54 & 6.79 & 5.83 & 4.56 \\
\hline 6 & 55.72 & 4.39 & 11.56 & 27.53 & 2.06 & 67.39 & 8.29 & 12.23 & 44.44 & 8.48 & 5.43 & 3.00 & 7.34 & 6.31 & 4.82 \\
\hline
\end{tabular}

Note: X1: plant height $(\mathrm{cm})$; X2: number of branches; X3: number of reproductive nodes; X4: number of filled pods; X5: number of unfilled pods; X6: number of seeds per plant; X7: seed yield per plant (g); X8: 100-seed weight (g); X9: pod length (mm); X10: pod width (mm); X11: pod thickness; X12: number of seeds per pod; X13: seed length (mm); X14: seed width (mm); X15: seed thickness $(\mathrm{mm})$. 


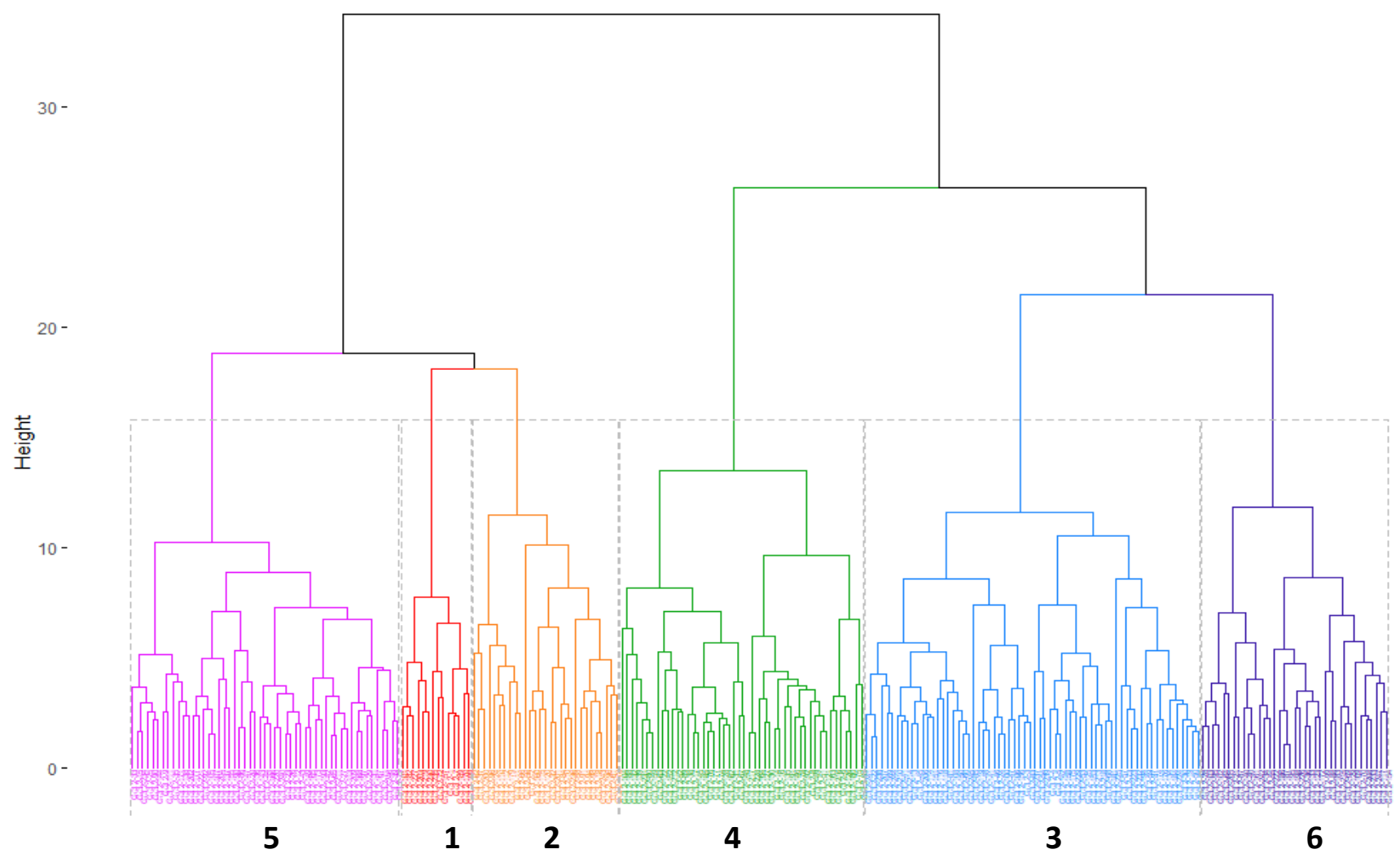

Figure 16. Cluster structure of Grobogan/UM 3-2

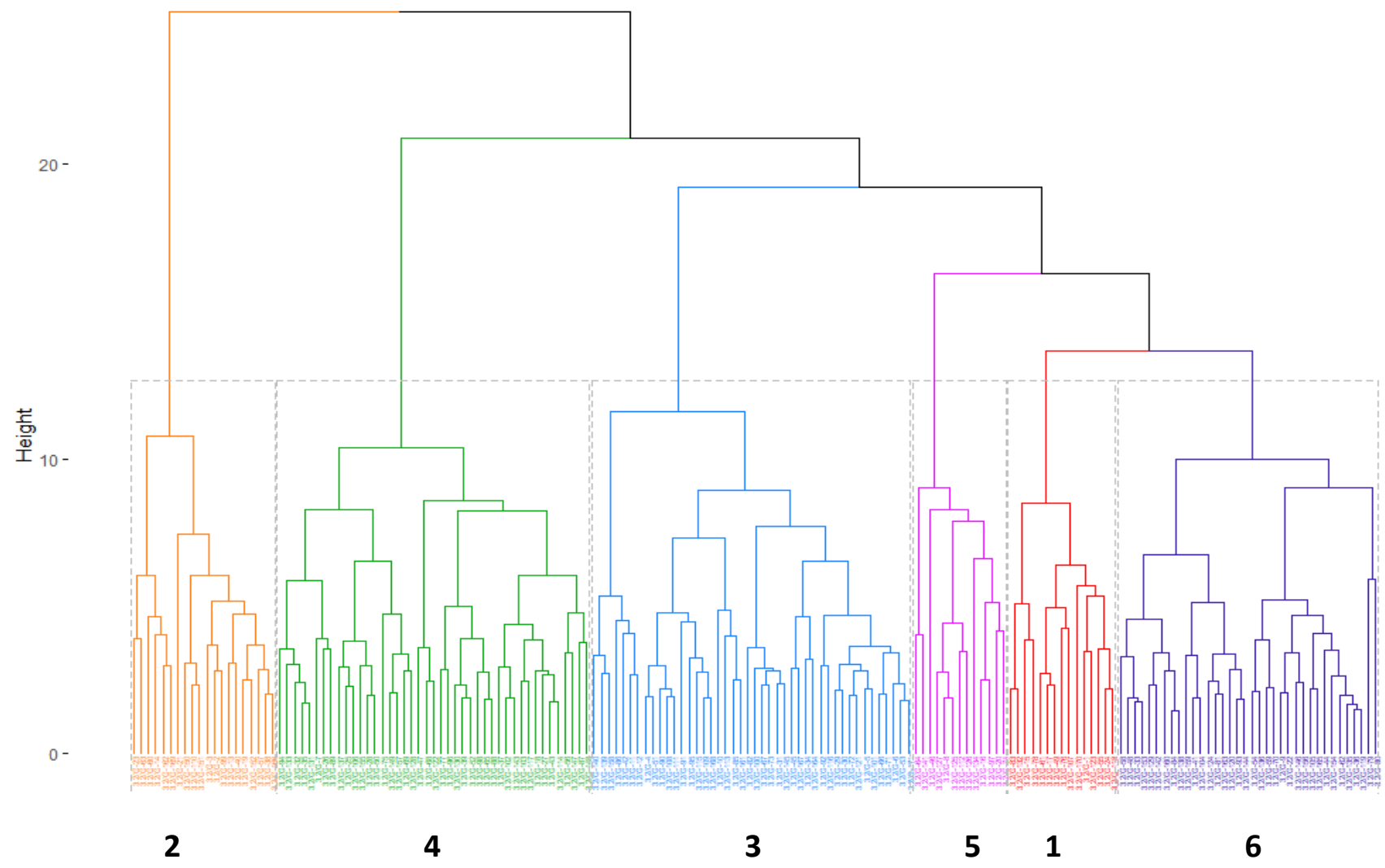

Figure 17. Cluster structure of UM 3-2/Grobogan 
Table 1 is also used to see the possibility of a maternal effect on the morphological characters of the F3 soybean Grobogan/UM 3-2 cross and its reciprocal UM 32/Grobogan. From this table, it can be seen that there was no maternal-effect on pod length, the number of seeds per pod, and seed length. These three characters may be inherited through a combination of genes from male and female parents. This result is consistent with Mebrahtu \& Devine (2008), who reported no maternal effect on pod length characters. Different results were presented by Ge et al. (2016), who found a maternal effect on seed length characters. This difference may be due to differences in the varieties or genotypes used in the study.

The maternal-effect was found on pod width, pod thickness, seed width, and seed thickness. This can be seen from the very significant differences in the four characters. So, it is likely that these four characters are influenced by the genes contained in the cytoplasm of the female parent gamete cell. This result is also supported by Ge et al. (2016), which states that there are indications of a maternal effect on the character of seed width and seed thickness. Similar results were reported by Liang et al. (2005), that the maternal effect largely controls the inheritance of the characters of seed width and seed thickness.

The range of values for the plant height in the Grobogan/UM 3-2 cross was 33-78 cm, while the UM 3$2 /$ Grobogan cross had a range of $37-69 \mathrm{~cm}$. The highest average value for the character of plant height was obtained by the UM 3-2/Grobogan cross, which was $56.03 \mathrm{~cm}$, while the Grobogan/UM 3-2 cross was $53.55 \mathrm{~cm}$ (Table 1). The variability of plant height in the two crosses was probably due to genetic diversity. Grobogan variety as the parent had a plant height ranging from 50-60 cm (Balitkabi, 2016), while the UM 3-2 soybean line had an average plant height of $57.08 \mathrm{~cm}$ (Setiawan et al. 2016). Plant height is one of the important characteristics in soybean production, mostly when harvesting is done mechanically.

For the number of branches, the range of values at the Grobogan/UM 3-2 cross was 1-8. The UM 3-2/Grobogan cross showed the range of values for the number of branches from 0-9. The Grobogan/UM 3-2 cross had the highest average number of branches as of 3.9, while the UM 3-2/Grobogan cross was 3.7 (Table 1). The number of branches with the number of productive nodes contributes to seed yield (Kuswantoro et al. 2014). Furthermore, the formation of branches in soybean plants depends on the plant growth type: determinate or indeterminate. In the indeterminate growth type, the branches will continue to grow after the flowering phase begins, while in the determinate growth type, the branches' growth will stop when the flowers start to appear (Agudamu et al. 2016).

The range of the number of productive nodes at Grobogan/UM 3-2 cross was 2-41, while for Grobogan/UM 3-2 cross was 6-25. The Grobogan/UM 3-2 cross had the highest average value for the number of productive nodes of 17.59, compared to the average for the UM 32/Grobogan cross of 11.95 (Table 1). Productive nodes are places where flowers will grow and become pods (Isnaini et al. 2020). Productive nodes are located on the stems and branches (Faot et al. 2019). Ferrari et al. (2018) explained that an increase in the number of branches would increase the number of productive nodes so that more shoots will grow to form flowers and pods.

The cross with the highest average value for the number of filled pods was Grobogan/UM 3-2, 38.85, while the average for the UM 3-2/Grobogan cross was 31.22 (Table 1). The number of filled pods in the Grobogan/UM 3-2 cross ranged from 16-105, while the characters for the number of filled pods at the UM 3-2/Grobogan cross ranged from 13-72. The number of filled pods is one of the characters that can affect the yield of dry seeds in soybean plants (Rodrigues et al. 2015). The number of productive nodes may influence the number of filled pods. Table 1 shows that the decrease in the average number of productive nodes will be followed by reducing the average number of filled pods. It is because productive nodes are the place where the flowers grow. Less productive nodes will reduce the number of flowers that will become pods. Kuswantoro (2017) found a positive correlation between the number of productive nodes and filled pods.

For the number of unfilled pods, the Grobogan/UM 3-2 cross had the highest average value, namely 1.7 . Meanwhile, the UM 3-2/Grobogan cross had an average value of 1.63 (Table 1). It indicates that the number of unfilled pods in the two crosses was very small. The low number of unfilled pods can be caused by planting soybeans in optimal conditions and minimal pest attack so that there are no obstacles in seed formation. According to Kuswantoro et al. (2019), generally, soybean plants grown in normal conditions and free from pests will have fewer unfilled pods. Soybean plants with a higher number of unfilled pods than filled pods will have low productivity (Isnaini et al. 2020).

The highest average value for the number of seeds per plant character was in the Grobogan/UM 3-2 cross (78.8), while the average value at the UM 3-2/Grobogan cross was 76.26 (Table 1). The range of values for the number of seeds per plant at the Grobogan/UM 3-2 cross was 33-235 seeds. The range the number of seeds per plant at the UM $3-2 /$ Grobogan cross was 28-179. The difference in the number of seeds per plant was likely influenced by genetic diversity. Suroso \& Sodik (2016) reported a very significant genetic effect on the number of seeds per plant. According to Aminah et al. (2020), the number of seeds per plant is a character that affects soybean yields.

The highest mean value was owned by the Grobogan/UM 3-2 cross on the seed yield per plant, 11.33 $\mathrm{g}$, while the average seed yield per plant of the UM 32/Grobogan cross was $9.9 \mathrm{~g}$ (Table 1). The range of seed weight values per at the Grobogan/UM 3-2 cross was 3.48$36.64 \mathrm{~g}$. The range of seed yield values per plant at the UM 3-2/Grobogan cross was 3.4-24.41 g. The seed yield per plant is a complex character because it is influenced by many other agronomic characters (Isnaini et al. 2020). One of the characters that affect the seed yield per plant is the number of filled pods (Kuswantoro et al. 2016).

The range of the 100-seed weight of the Grobogan/UM 3-2 cross was 7.6-19.76 g., while the range of 100-seed weight of the UM 3-2/Grobogan crosses was 8.72-17.24 g. The Grobogan/UM 3-2 cross showed the highest average 
value for the 100 -seed weight character, $14.33 \mathrm{~g}$, while the 100-seed weight average value at the UM 3-2/Grobogan cross was $12.93 \mathrm{~g}$ (Table 1). The 100 -seed weight measures seed size. The large seed size in the Grobogan/UM 3-2 cross is likely inherited from the Grobogan variety, which has large seeds, with a 100-seed weight of $18 \mathrm{~g}$ (Balitkabi 2016). 100-seed weight is also positively correlated with the seed yield per plant and the number of productive nodes (Faot et al. 2019).

The Grobogan/UM 3-2 cross has the highest value for the pod length $(43.51 \mathrm{~mm})$, pod width $(9.14 \mathrm{~mm})$, and pod thickness $(5.75 \mathrm{~mm})$, while the UM 3-2/Grobogan cross has the highest value. For of pod length $(42.65 \mathrm{~mm})$, pod width $(8.09 \mathrm{~mm})$, pod thickness $(5.46 \mathrm{~mm})$ (Table 1$)$. The differences in the length, width, and thickness of the pods were probably due to genetic factors. It is also confirmed by Ningsih et al. (2019), who found the influence of genetic factors on the length, width, and thickness of pods.

The UM 3-2/Grobogan cross obtained the highest average value for the number of seeds per pod, which was 2.74. Meanwhile, at the Grobogan/UM 3-2 cross, the average value for the number of seeds per pod was 2.71 (Table 1). The number of seeds per pod in the Grobogan/UM 3-2 cross ranged from 2-4. The number of seeds per pod at the UM 3-2/Grobogan cross has a range of values of 2-4. The number of seeds per pod may be influenced by genetic diversity. This result was also confirmed by Malek et al. (2014), who found differences in the number of seeds per pod among observed soybean genotypes

Morphological characters observed in this study were seed length, seed width, and seed thickness. The UM 32/Grobogan cross obtained the highest average value for the seed length, which was 2.74. Meanwhile, the average seed length value at the Grobogan/UM 3-2 cross was 7.38 $\mathrm{mm}$. The Grobogan/UM 3-2 cross had the highest average value in the seed width, namely $6.41 \mathrm{~mm}$, while the UM 3$2 /$ Grobogan cross had an average value of 6.25 . For the grain thickness, the Grobogan/UM 3-2 cross had the highest average value of $5.01 \mathrm{~mm}$, while the UM 3$2 /$ Grobogan cross had an average value of $4.86 \mathrm{~mm}$. The seed length, seed width, and seed thickness were most likely influenced by genetic diversity. Ningsih et al. (2019) stated significant differences in the seed length, seed width, and seed thickness between the observed soybean lines.

Based on Table 3, at the Grobogan/UM 3-2 cross, the best individuals for the character number of branches, number of productive nodes, number of filled pods, number of unfilled pods, number of seeds per plant, and seed yield per plant, can be obtained from the cluster. 2. For the 100seed weight character, pod length, pod width, pod thickness, seed width, and seed thickness, the best individuals can be obtained from Cluster 1. Meanwhile, based on Table 5, at the UM 3-2/Grobogan cross, The best individuals for plant height characters can be obtained from Cluster 2, while seed length can be obtained from Cluster 3 . For characters, the best number of seeds per pod can be obtained from Cluster 6. Character differences in each cluster of the two crosses probably were caused by the maternal effect.
The maternal effects on agronomic characters were found in the plant height, number of productive nodes, number of filled pods, seed yield per plant and 100-seed weight. On morphology characters, maternal effect was found in pod width and thickness and seed width and thickness. The maternal effect changed the cluster structure of F3 generation by showing different cluster between the two crosses. To accelerate breeding program for these nine characters, the breeder should aware of the parents' crossing method.

\section{ACKNOWLEDGEMENTS}

The authors have the same contribution (all authors are the main contributors) to this article. DRPM DIKTI funds this article's publication for The Higher Education Basic Research grant funding No. 1.3.44/un32.14/1t/2018.

\section{REFERENCES}

Agudamu, Yoshihira T, Shiraiwa T. 2016. Branch development responses to planting density and yield stability in soybean cultivars. Plant Prod Sci 19 (3): 331-339. DOI: 10.1080/1343943X.2016.1157443.

Aminah, Abdullah, Nuraeni, Palad MS, Rosada I. 2020. Effectiveness of water management towards soil moisture preservation on soybeans. Intl J Agron 1-5. DOI: 10.1155/2020/8653472.

Balitkabi. 2016. Description of Soybean Superior Varieties 1918-2016. Indonesian Legume and Tuber Crops Research Institute, Malang. [Indonesian]

Faot MM, Zubaidah S, Kuswantoro H. 2019. Genetic correlation and path analysis of agronomical traits of soybean (Glycine max) lines infected by CpMMV. Biodiversitas 20 (6): 1496-1503. DOI: 10.13057/biodiv/d200602

Ferrari M, Carvalho IR, de Pelegrin AJ, Nardino M, Szareski VJ, Olivoto T, da Rosa TC, Follmann DN, Pegoraro C, da Maia LC, de Souza VQ. 2018. Path analysis and phenotypic correlation among yield components of soybean using environmental stratification methods. $\begin{array}{llllll}\text { Aust J Crop Sci } 12 & \text { (2): 193-202. DOI: }\end{array}$ 10.21475/ajcs.18.12.02.pne488

Ge L, Yu J, Wang H, Luth D, Bai G, Wang K, Chen R. 2016. Increasing seed size and quality by manipulating BIG SEEDS1 in legume species. Proc Natl Acad Sci USA. DOI: 10.1073/pnas.1611763113

Gilsinger JJ, Burton JW, Carter TE. 2010. Maternal effects on fatty acid composition of soybean seed oil. Crop Sci 50 (5): 1874-1881. DOI: 10.2135/cropsci2009.09.0553

Hidayatullah AF, Zubaidah S, Kuswantoro H. 2017. Karakter morfologi polong galur kedelai hasil persilangan varietas introduksi dari Korea dengan varietas Indonesia. Prosiding Seminar Pendidikan IPA Pascasarjana UM 2: 381-389. [Indonesian]

Isnaini A, Zubaidah S, Kuswantoro H. 2020. Maternal effect of agronomical characters of F1 soybean derived from Panderman variety and CpMMV-resistant soybean lines. Proceedings of The International Conference on Life Sciences and Technology (ICoLiST). Universitas Negeri Malang, 22 April 2020. DOI: $10.1063 / 5.0002443$

Julia N, Zubaidah S, Kuswantoro H. 2019. Morphological and anatomical characteristics of leaves of ten soybeans (Glycine max L. Merill) lines. IOP Conf Ser Earth Environ Sci. DOI:10.1088/1755$1315 / 276 / 1 / 012027$

Kuswantoro H, Ginting E, Utomo JS, Yusnawan E. 2019. Performance of agronomical and seed biochemical traits of soybean genotypes in relation to their tolerance and preference by Nezara viridula. Biodiversitas 20 (2): 356-363. DOI: 10.13057/biodiv/d200208.

Kuswantoro H, Indriani FC, Patriawaty NR, Sulistyo A, Han WY, Lee PY, Cho YH, Baek IY. 2014. Performance of acid-adaptive soybean expected lines in south Lampung, Indonesia. Agrivita 36: 160-166. 
Kuswantoro H, Ujianto L, Sulistyo A, Hapsari T. 2016. Yields and yield components of soybean lines at two locations. J Agron Indones 44 26-32. [Indonesian]

Kuswantoro H. 2017. Genetic variability and heritability of acid-adaptive soybean promising lines. Biodiversitas 18 (1): 378-382. DOI: 10.13057/biodiv/d180149.

Liang HZ, Li WD, Wang H, Fang XJ. 2005. Genetic effects on seed traits in soybean. Acta Genet Sin 32: 1199-1204

Malek MA, Rafii MY, Afroz, MSS, Nath, UK, Mondal MMA. 2014. Morphological characterization and assessment of genetic variability, character association, and divergence in soybean mutants. Sci World J 1-12. DOI: $10.1155 / 2014 / 968796$.

Mebrahtu T, Devine TE. 2008. Combining ability analysis for selected green pod yield components of vegetable soybean genotypes (Glycine max). N Z J Crop Hortic Sci 36 (2): 97-105. DOI: 10.1080/01140670809510225

Ministry of Agriculture. 2018. Production, harvested area and productivity of secondary crops in Indonesia 2014-2018. https://www.pertanian.go.id/Data5tahun/TPATAP-2017(pdf)/01PalawijaNasional.pdf [Indonesian]

Ningsih F, Zubaidah S, Kuswantoro H. 2017. Karakteristik agronomi plasma nutfah kedelai (Glycine max L. Merill). Prosiding Seminar Pendidikan IPA Pascasarjana UM 2: 437-444. [Indonesian]
Ningsih F, Zubaidah S, Kuswantoro H. 2019. Diverse morphological characteristics of soybean (Glycine max L. Merill) pods and seeds germplasm. IOP Conf Ser Earth Environ Sci. DOI: 10.1088/17551315/276/1/012014.

Roach DA, Wulff RD. 1987. Maternal effects in plants. Ann Rev Ecol Syst 18: 209-235.

Rodrigues B, Serafim F, Nogueira APO, Hamawaki OT, de Sousa LB, Hamawaki RL. 2015. Correlations between traits in soybean (Glycine $\max$ L.) naturally infected with Asian rust (Phakopsora pachyrhizi). Genet Mol Res 14 (4): 17718-17729. DOI: 10.4238/2015.December.21.45.

Setiawan TA, Zubaidah S, Kuswantoro H. 2016. Morphology of CpMMV (Cowpea Mild Mottle Virus) resistant soybean lines as a source of biology learning. Bioedukasi J Pendidik Biologi 7: 363-368. [Indonesian]

Suroso B, Sodik AJ. 2016. Yield potential and contribution of agronomic properties to soybean (Glycine max L. Merril) yields in monoculture cropping systems. Agritrop J Ilmu-Ilmu Pertan 14 (2): 1-10. DOI: 10.32528/agr.v14i2.427. [Indonesian]

Syukur M, Sujiprihati S, Yunianti R. 2015. Plant Breeding Techniques. Bogor Agricultural University (IPB), Bogor. [Indonesian] 